\title{
Direct contribution of nitrogen deposition to nitrous oxide emissions in a temperate beech and spruce forest $-a^{15} \mathrm{~N}$ tracer study
}

\author{
N. Eickenscheidt, R. Brumme, and E. Veldkamp \\ Soil Science of Tropical and Subtropical Ecosystems, Buesgen Institute, University of Goettingen, Buesgenweg 2, \\ 37077 Goettingen, Germany
}

Received: 29 September 2010 - Published in Biogeosciences Discuss.: 12 November 2010

Revised: 9 February 2011 - Accepted: 10 February 2011 - Published: 8 March 2011

\begin{abstract}
The impact of atmospheric nitrogen (N) deposition on nitrous oxide $\left(\mathrm{N}_{2} \mathrm{O}\right)$ emissions in forest ecosystems is still unclear. Our study assessed the direct contribution of $\mathrm{N}$ deposition to $\mathrm{N}_{2} \mathrm{O}$ emissions in temperate forests exposed to chronic high $\mathrm{N}$ depositions using a ${ }^{15} \mathrm{~N}$ labelling technique. In a Norway spruce stand (Picea abies) and in a beech stand (Fagus sylvatica) at the Solling, Germany, we used a low concentrated ${ }^{15} \mathrm{~N}$-labelled ammoniumnitrate solution to simulate $\mathrm{N}$ deposition. Nitrous oxide fluxes and ${ }^{15} \mathrm{~N}$ isotope abundances in $\mathrm{N}_{2} \mathrm{O}$ were measured using the closed chamber method combined with ${ }^{15} \mathrm{~N}$ isotope analyses. Emissions of $\mathrm{N}_{2} \mathrm{O}$ were higher in the beech stand $\left(2.6 \pm 0.6 \mathrm{~kg} \mathrm{Nha}^{-1} \mathrm{yr}^{-1}\right)$ than in the spruce stand $\left(0.3 \pm 0.1 \mathrm{~kg} \mathrm{Nha}^{-1} \mathrm{yr}^{-1}\right)$. We observed a direct effect of $\mathrm{N}$ input on ${ }^{15} \mathrm{~N}-\mathrm{N}_{2} \mathrm{O}$ emissions, which lasted for less than three weeks and was mainly caused by denitrification. No further increase in ${ }^{15} \mathrm{~N}$ enrichment of $\mathrm{N}_{2} \mathrm{O}$ occurred during a one-year experiment, which was probably due to immobilisation of deposited $\mathrm{N}$. The annual emission factor for $\mathrm{N}_{2} \mathrm{O}$ from deposited $\mathrm{N}$ was $0.1 \%$ for the spruce stand and $0.6 \%$ for the beech stand. Standard methods used in the literature applied to the same stands grossly overestimated emission factors with values of up to $25 \%$. Only $6-13 \%$ of the total $\mathrm{N}_{2} \mathrm{O}$ emissions were derived from direct $\mathrm{N}$ depositions. Whether the remaining emissions resulted from accumulated anthropogenic $\mathrm{N}$ depositions or native soil $\mathrm{N}$, could not be distinguished with the applied methods. The ${ }^{15} \mathrm{~N}$ tracer technique is a useful tool, which may improve estimates of the current contribution of $\mathrm{N}$ deposition to $\mathrm{N}_{2} \mathrm{O}$ emissions.
\end{abstract}

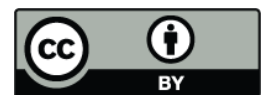

Correspondence to: N. Eickenscheidt (neicken@gwdg.de)

\section{Introduction}

In Europe and in many other parts of the world, emissions of reactive nitrogen $(\mathrm{N})$ have rapidly increased in the last decades mainly due to agricultural and industrial activities (e.g. Galloway et al., 2008; Vitousek et al., 1997). As a consequence, European forests have been exposed to high deposition rates of acidity and reactive $\mathrm{N}$ compounds (Berge et al., 1999). Pre-industrial European forests were supposed to be $\mathrm{N}$-limited, however widespread $\mathrm{N}$ deposition has caused a shift in the forest's $\mathrm{N}$ status which under chronic $\mathrm{N}$ deposition may even lead to $\mathrm{N}$-saturated conditions (Aber et al., 1998). Using N input-output balances, Brumme and Khanna (2008, 2009b) classified German forests into four groups with different $\mathrm{N}$ status that cover the complete $\mathrm{N}$ enrichment continuum. According to them "steady state type forests" with mull type humus (STFa: forests where deposited $\mathrm{N}$ is accumulating in trees only and not in the soil) were probably widespread in Europe in pre-industrial times. They assumed that soil acidification caused these forests to lose organic matter and mineral $\mathrm{N}$ from the soil changing them into "degradation type forests" (DTF: forests where the mineral soil has become a source of $\mathrm{N}$ and $\mathrm{C}$ ). With further acid and $\mathrm{N}$ depositions, these forests would change into "accumulation type forests" (ATF: forests where deposited N and carbon is accumulating in the surface organic soil). At the end of the $\mathrm{N}$ enrichment continuum, forests could become another "steady state type forests" with moder type humus ( $\mathrm{STFb}$ : forests where deposited $\mathrm{N}$ is accumulating in trees and not in soil). Fluxes of nitrous oxide $\left(\mathrm{N}_{2} \mathrm{O}\right)$, which is an important greenhouse gas (IPCC, 2007) and contributes to the chemical destruction of the stratospheric ozone layer (Crutzen, 1979), may increase if the soil becomes a source of $\mathrm{N}$ (transition from STFa $\rightarrow$ DTF) and deposited N exceeds the storage capacity of the ecosystem (transition from

Published by Copernicus Publications on behalf of the European Geosciences Union. 
$\mathrm{ATF} \rightarrow \mathrm{STFb}$ ). Consequently, European forests with chronic acid and $\mathrm{N}$ deposition frequently act as considerable source for $\mathrm{N}_{2} \mathrm{O}$ (e.g. Brumme and Beese, 1992; Butterbach-Bahl et al., 1998; Papen and Butterbach-Bahl, 1999; Skiba et al., 1999).

Temperate forest soils are estimated to add between 0.1 and 2.0 $\mathrm{Tg} \mathrm{N}_{2} \mathrm{O}-\mathrm{N} \mathrm{yr}^{-1}$ to the atmosphere, which is between 0.6 and $11 \%$ of the total global $\mathrm{N}_{2} \mathrm{O}$ emissions (Brumme et al., 2005; IPCC, 2001; Kroeze et al., 1999) indicating the high degree of uncertainty in the estimations. The role of atmospheric $\mathrm{N}$ depositions on $\mathrm{N}_{2} \mathrm{O}$ emissions is highly unclear and is one of the reasons for this uncertainty (Pilegaard et al., 2006). The IPCC (2006) uses a default emission factor for $\mathrm{N}_{2} \mathrm{O}$ of 0.01 , which means that $1 \%$ of the $\mathrm{N}$ deposited in temperate forests contributes to $\mathrm{N}_{2} \mathrm{O}$ emissions. The uncertainty of this emission factor is huge ranging from 0.002 to 0.05 where the higher fraction comes from deciduous forests and the lower fraction from coniferous forests (Brumme et al., 1999; Denier van der Gon and Bleeker, 2005). Tree species related differences in litter quality, litter structure, and soil moisture may play a role in the reported variation of emission factors, but still much uncertainty remains (Brumme et al., 1999; Pilegaard, 2006).

Three different approaches have been used to examine the impact of $\mathrm{N}$ depositions on $\mathrm{N}_{2} \mathrm{O}$ fluxes: (1) regression analysis between $\mathrm{N}$ depositions and $\mathrm{N}_{2} \mathrm{O}$ fluxes (e.g. ButterbachBahl et al., 1998), (2) comparison of similar forest ecosystems receiving different $\mathrm{N}$ loads (e.g. Skiba et al., 1999), and (3) $\mathrm{N}$ fertilisation experiments (e.g. Brumme and Beese, 1992). These approaches have the following limitations: (1) regression analysis between $\mathrm{N}$ depositions and $\mathrm{N}_{2} \mathrm{O}$ fluxes requires a strong correlation, which can only occur if direct $\mathrm{N}_{2} \mathrm{O}$ emission of deposited $\mathrm{N}$ is significant. Moreover, $\mathrm{N}$ deposition is usually correlated with similar factors (e.g. precipitation) that also control $\mathrm{N}_{2} \mathrm{O}$ fluxes (ButterbachBahl et al., 1998; Kitzler et al., 2006a). (2) Comparing sites receiving different $\mathrm{N}$ loads has the limitation that sites are usually not completely comparable in climate and soil properties. Finally, (3) studies have shown that the application of mineral $\mathrm{N}$ to simulate $\mathrm{N}$ deposition does not commonly reflect the mode of chronic N depositions (Sitaula et al., 1995; Skiba and Smith, 2000).

The use of ${ }^{15} \mathrm{~N}$ isotopes as a tracer is potentially a useful technique to investigate the impact of $\mathrm{N}$ deposition on $\mathrm{N}_{2} \mathrm{O}$ fluxes in forests. The ${ }^{15} \mathrm{~N}$ technique can be applied even if low direct $\mathrm{N}_{2} \mathrm{O}$ emissions occur, it is independent of precipitation amount and does not cause artificially high mineral $\mathrm{N}$ concentrations in the soil. At present we are not aware of any study where the emission factor for $\mathrm{N}_{2} \mathrm{O}$ from forest soils was estimated using ${ }^{15} \mathrm{~N}$ tracer techniques. In forest ecosystems the ${ }^{15} \mathrm{~N}$ tracing technique has only been used to distinguish between various sources of $\mathrm{N}_{2} \mathrm{O}$ production (e.g. Ambus et al., 2006; Wolf and Brumme, 2002).

Our objectives were (i) to examine the direct contributions of ammonium $\left(\mathrm{NH}_{4}^{+}\right)$and nitrate $\left(\mathrm{NO}_{3}^{-}\right)$depositions to $\mathrm{N}_{2} \mathrm{O}$ emissions and (ii) to follow the effect for one year including the remineralisation of deposited and subsequently immobilised N. We hypothesise that (1) N depositions contribute considerably to direct $\mathrm{N}_{2} \mathrm{O}$ emissions which is caused by the availability of mineral $\mathrm{N}$ independent of mineralisation and nitrification rates and (2) $\mathrm{N}$ depositions contribute to significant amounts of $\mathrm{N}_{2} \mathrm{O}$ emissions over one-year because of remineralisation of deposited $\mathrm{N}$. To test our hypotheses, we conducted (i) a short-term as well as (ii) a one-year long lasting in situ ${ }^{15} \mathrm{~N}$ tracer experiment in a coniferous and in a deciduous forest stand which both have been exposed to high atmospheric $\mathrm{N}$ depositions for decades.

\section{Materials and methods}

\subsection{Study area}

The study was carried out at the Solling plateau in Central Germany $\left(51^{\circ} 46^{\prime} \mathrm{N}, 9^{\circ} 34^{\prime} \mathrm{E}\right.$; $500 \mathrm{~m}$ a.s.l.; mean annual temperature: $6.9^{\circ} \mathrm{C}$; annual precipitation: $1193 \mathrm{~mm}$ ). The soil type is an acidic Dystric Cambisol (silt loam), which has developed in a loess solifluction layer overlying Triassic sandstone bedrock. The humus type is a typical moder. A detailed site description is given by Bredemeier et al. (1995, 1998) and by Brumme and Khanna (2009a). Experiments took place in a 74-yr-old Norway spruce stand (Picea abies (L.) Karst.) and in an adjacent 160-yr-old beech stand (Fagus sylvatica). Soil characteristics for both sites are presented in Table 1.

Both stands have been exposed to high $\mathrm{N}$ depositions for decades. In 2007 and 2008, stand deposition amounted to $33 \mathrm{~kg} \mathrm{Nha}^{-1} \mathrm{yr}^{-1}$ in the spruce stand with $\mathrm{NH}_{4}^{+}-\mathrm{N}^{-\mathrm{NO}_{3}^{-}}$$\mathrm{N}: \mathrm{N}_{\text {org }}$ in the ratios of $49: 44: 7$ and to $20 \mathrm{~kg} \mathrm{Nha}^{-1} \mathrm{yr}^{-1}$ in the beech stand with a $\mathrm{NH}_{4}^{+}-\mathrm{N}^{-N_{3}^{-}}-\mathrm{N}: \mathrm{N}_{\text {org }}$ ratio of 47:38:16. Stand $\mathrm{N}$ deposition was usually measured in monthly intervals in both stands and represents the sum of throughfall deposition and stemflow. Stemflow was negligible in the spruce stand. In the beech stand, data collection and chemical analyses were conducted by the Northwest German Forest Research Station (Meesenburg et al., 2009).

\subsection{Experimental design}

We conducted the short-term experiment in August and September 2009 in order to examine the direct contribution of $\mathrm{NH}_{4}^{+}$and $\mathrm{NO}_{3}^{-}$depositions to $\mathrm{N}_{2} \mathrm{O}$ emissions. Ten chamber bases were randomly installed in each stand, four of which were labelled once with ${ }^{15} \mathrm{NH}_{4} \mathrm{NO}_{3}$ solution (named $\mathrm{NH}_{4}^{+}$-labelled) whereas the other four were labelled once with $\mathrm{NH}_{4}^{15} \mathrm{NO}_{3}$ solution (named $\mathrm{NO}_{3}^{-}$-labelled; both contained 98 atom $\%{ }^{15} \mathrm{~N}$ ). Two chambers served as controls. We reduced the number of control chambers in favour of treated chambers because the temporal as well as spatial variability of emitted natural ${ }^{15} \mathrm{~N}$ in our previous studies in the beech 
Table 1. Soil characteristics of the spruce and beech stands at the Solling site.

\begin{tabular}{lllllllll}
\hline $\begin{array}{l}\text { Soil depth } \\
\text { and forest site }\end{array}$ & $n$ & $\mathrm{pH}\left(\mathrm{H}_{2} \mathrm{O}\right)$ & $n \begin{array}{l}\text { Total organic carbon } \\
{\left[\mathrm{mg} \mathrm{Cg}^{-1}\right]}\end{array}$ & $\begin{array}{l}\text { Total nitrogen } \\
{\left[\mathrm{mg} \mathrm{Ng}^{-1}\right]}\end{array}$ & $\mathrm{C} / \mathrm{N} \mathrm{ratio}$ & $\begin{array}{l}\text { Bulk density } \\
{\left[\mathrm{g} \mathrm{cm}^{-3}\right]}\end{array}$ & $\begin{array}{l}\text { Humus mass } \\
{\left[\mathrm{Mg} \mathrm{ha}^{-1}\right]}\end{array}$ \\
\hline Organic layer & & & & & & & \\
\hline $\begin{array}{l}\text { Spruce } \\
\text { Beech }\end{array}$ & 3 & $3.6(0.1)^{\mathrm{a}}$ & 13 & $447(13)$ & $16.5(0.4)^{\mathrm{a}}$ & $27.2(0.6)^{\mathrm{a}}$ & 6 & $67.1(4.4)^{\mathrm{a}}$ \\
\hline $0-5 \mathrm{~cm}$ & & $4.0(0.0)^{\mathrm{b}}$ & 13 & $443(12)$ & $18.6(0.7)^{\mathrm{b}}$ & $24.1(0.7)^{\mathrm{b}}$ & 6 & $35.6(1.9)^{\mathrm{b}}$ \\
\hline Spruce & 6 & $3.3(0.0)$ & 14 & $112(7)$ & & & & \\
Beech & 6 & $3.4(0.0)$ & 14 & $98(11)$ & $4.6(0.3)$ & $24.3(0.8)^{\mathrm{a}}$ & 4 & $0.76(0.03)$ \\
\hline $5-10 \mathrm{~cm}$ & & & & & & $21.7(1.4)^{\mathrm{b}}$ & 6 & $0.89(0.02)$ \\
\hline Spruce & 5 & $3.5(0.0)$ & 13 & $39(2)^{\mathrm{a}}$ & $1.7(0.1)$ & $22.9(0.8)^{\mathrm{a}}$ & 5 & $1.00(0.02)$ \\
Beech & 6 & $3.6(0.0)$ & 13 & $32(2)^{\mathrm{b}}$ & $1.7(0.1)$ & $19.8(1.1)^{\mathrm{b}}$ & 6 & $1.08(0.04)$ \\
\hline
\end{tabular}

At each layer, means $( \pm \mathrm{SE})$ followed by different letters indicated differences among the spruce and beech stands (independent t-test or Mann-Whitney $\mathrm{U}$-test at $P \leq 0.05$ ).

stand indicated low values (see Supplement). We added $0.7 \mathrm{~L}$ labelling solution per chamber base. The $\mathrm{N}$ concentration of the solution was $1.65 \mathrm{mg} \mathrm{L}^{-1}$, which was within the range of the $\mathrm{N}$ concentrations measured in the throughfall. The labelled $\mathrm{N}$ was distributed down to $10 \mathrm{~cm}$ mineral soil depth within few hours after the application. In addition to the fluxes of $\mathrm{N}_{2} \mathrm{O}$ and ${ }^{15} \mathrm{~N}-\mathrm{N}_{2} \mathrm{O}$, we determined air and soil temperature, soil moisture, and extractable mineral $\mathrm{N}\left(\mathrm{N}_{\min }=\right.$ $\left.\mathrm{NH}_{4}^{+}-\mathrm{N}+\mathrm{NO}_{3}^{-}-\mathrm{N}\right)$ content. Soil samples were taken at randomly chosen locations between the chamber bases. Measurements were conducted $3.5 \mathrm{~h}$ (spruce) and $5 \mathrm{~h}$ (beech), $24 \mathrm{~h}, 48 \mathrm{~h}, 7$ days, and 21 days after the application of labelled $\mathrm{N}$.

The one-year experiment was performed to examine the impact of $\mathrm{NH}_{4}^{+}$and $\mathrm{NO}_{3}^{-}$deposition on $\mathrm{N}_{2} \mathrm{O}$ emissions including the remineralisation of the deposited $\mathrm{N}$ within one year. At both stands we randomly installed 17 chamber bases for gas flux measurements and soil sampling. Seven of the chamber bases received a ${ }^{15} \mathrm{NH}_{4} \mathrm{NO}_{3}$ solution (named $\mathrm{NH}_{4}^{+}$-labelled; 98 atom $\%{ }^{15} \mathrm{~N}$ ) and another seven received a ${ }^{15} \mathrm{NH}_{4}^{15} \mathrm{NO}_{3}$ solution (named $\mathrm{NH}_{4} \mathrm{NO}_{3}$-labelled; 95 atom $\%{ }^{15} \mathrm{~N}$ ). Of the seven chamber bases, five were used for gas flux measurements whereas soil samples were taken in two chamber bases. Three chamber bases served as controls for $\mathrm{N}_{2} \mathrm{O}$ and ${ }^{15} \mathrm{~N}-\mathrm{N}_{2} \mathrm{O}$ fluxes. All measurements as described above in the short-term experiment were also carried out in this experiment which was conducted from May 2007 to June 2008. Measurements were done every second week in the summer months and monthly in the winter months. Uncertainties that arise from the frequency of measurements are probably low. A published study done in our beech stand (Brumme and Beese, 1992) revealed that during the season with high emissions weekly measurements overestimated $\mathrm{N}_{2} \mathrm{O}$ fluxes by $3 \%$ to $11 \%$ compared to measurements with an automatic chamber (five measurements per day). Overestimation will presumable be lower when covering the whole year. The ${ }^{15} \mathrm{~N}$ solution was always applied one week before the gas flux measurements (18 applications over the year). For one $\mathrm{N}$ application in the one-year experiment, the amount of $\mathrm{N}$ and water added were equal to the amount added with one application in the short-term experiment. To each chamber receiving $\mathrm{N}$ we added the equivalent of $0.78 \mathrm{~kg} \mathrm{Nha}^{-1} \mathrm{yr}^{-1}$, which was $2.4 \%$ of the annual deposition in the spruce stand and $3.8 \%$ in the beech stand. The amount of water added was equivalent to $47 \mathrm{~mm}$ rain, which was approx. $4.8 \%$ of the annual precipitation.

\section{$2.3 \quad \mathrm{~N}_{2} \mathrm{O}$ and ${ }^{15} \mathrm{~N}-\mathrm{N}_{2} \mathrm{O}$ measurements}

Fluxes of $\mathrm{N}_{2} \mathrm{O}$ were measured using the closed chamber method (static, vented chambers made of PVC; area: $0.2665 \mathrm{~m}^{2}$; vol.: 18.9-29.3 L (beech), 27.5-34.7 L (spruce)). Gas samples of $100 \mathrm{~mL}$ were removed at three (May 2007 to January 2008) or four (February to June 2008 and 2009) regular time intervals following chamber closure (42 min at most) using a portable gas sampler equipped with a pressure sensor (Loftfield et al., 1997). The pressure sensor was used to check the leak tightness of the evacuated glass bottles prior to sampling and to ensure that bottles were completely filled with "chamber air". Analysis of $\mathrm{N}_{2} \mathrm{O}$ was carried out with a gas chromatograph equipped with an EC detector (GC 14A, Shimadzu, Duisburg, Germany). Fluxes of $\mathrm{N}_{2} \mathrm{O}$ were calculated from the linear change of $\mathrm{N}_{2} \mathrm{O}$ concentrations in the chamber versus time, after fluxes were adjusted for air temperature and atmospheric pressure. We tested a quadratic model for some data, but no clear advantage of the non-linear model emerged from the statistical indicators for the goodness of fit. Additionally, $\mathrm{N}_{2} \mathrm{O}$ fluxes calculated using the quadratic model were not significantly different from fluxes calculated using the linear model. We further think 
that scattering of $\mathrm{N}_{2} \mathrm{O}$ concentrations due to random errors during sampling and measurement were much larger than the effect of the chamber on the gas exchange and possible biases due to linear regression. The cumulative mean annual flux was calculated using the trapezoid rule. Samples for ${ }^{15} \mathrm{~N}-\mathrm{N}_{2} \mathrm{O}$ analysis were collected in glass bottles $(100 \mathrm{~mL})$ closed with a butyl-hallow stopper at time point zero and after 24 to 28 min. Analysis of ${ }^{15} \mathrm{~N}$ in $\mathrm{N}_{2} \mathrm{O}$ was done using an isotope ratio mass spectrometer coupled with a preconcentration unit (PreCon-GC-IRMS, Thermo Finnigan MAT, Bremen, Germany).

\subsection{Chemical analyses}

Mineral $\mathrm{N}$ was extracted after shaking 25 to $30 \mathrm{~g}$ fresh mineral soil with $100 \mathrm{~mL} 0.5 \mathrm{M} \mathrm{K}_{2} \mathrm{SO}_{4}$ solution or $15 \mathrm{~g}$ of the organic layer with $50 \mathrm{~mL} \mathrm{~K}_{2} \mathrm{SO}_{4}$ solution, using pre-washed filter papers. Extracts of $\mathrm{K}_{2} \mathrm{SO}_{4}$ were frozen until analysis. Mineral $\mathrm{N}$ analysis was carried out using continuous flow injection colorimetry (Cenco/Skalar Instruments, Breda, The Netherlands). The water content was determined gravimetrically. Soil bulk density was determined using undisturbed soil samples that were oven-dried at $105^{\circ} \mathrm{C}$ and sieved to $2 \mathrm{~mm}$ to remove stones and living roots. The mass of the organic layer was measured using a metal ring $\left(594 \mathrm{~cm}^{2}\right)$. Organic layer samples were oven-dried at $60^{\circ} \mathrm{C}$ and living roots were removed. Total carbon and nitrogen measurements were done using a CNS Elemental Analyzer (Heraeus Elementar Vario EL, Hanau, Germany) and ${ }^{15} \mathrm{~N}$ concentrations using a Delta $\mathrm{C}$ plus isotope ratio mass spectrometer (Finnigan MAT, Bremen, Germany). The $\mathrm{pH}$ was determined in distilled water $(1: 2.5(v / v))$ using $10 \mathrm{~mL}$ sieved soil or shredded organic material.

\subsection{Calculation of ${ }^{15} \mathrm{~N}$ abundance}

Isotope abundances were expressed in absolute proportion [atom \%]:

${ }^{15} \mathrm{~N}[$ atom $\%]=\frac{{ }^{15} \mathrm{~N}}{{ }^{15} \mathrm{~N}+{ }^{14} \mathrm{~N}} \cdot 100$

The ${ }^{15} \mathrm{~N}-\mathrm{N}_{2} \mathrm{O}$ abundance of $\mathrm{N}_{2} \mathrm{O}$ emitted from the soil was calculated using the Keeling plot approach (Pataki et al., 2003; Tilsner et al., 2003):

${ }^{15} \mathrm{~N}_{\text {emitted }}=$
$\frac{{ }^{15} \mathrm{~N}_{\text {chamber air }} \cdot c\left(\mathrm{~N}_{2} \mathrm{O}\right)_{\text {chamber air }}-{ }^{15} \mathrm{~N}_{\text {ambient air }} \cdot c\left(\mathrm{~N}_{2} \mathrm{O}\right)_{\text {ambient air }}}{c\left(\mathrm{~N}_{2} \mathrm{O}\right)_{\text {chamber air }}-c\left(\mathrm{~N}_{2} \mathrm{O}\right)_{\text {ambient air }}}$

where $c\left(\mathrm{~N}_{2} \mathrm{O}\right)$ is the concentration of $\mathrm{N}_{2} \mathrm{O}$ and ${ }^{15} \mathrm{~N}$ is the abundance of ${ }^{15} \mathrm{~N}$ in $\mathrm{N}_{2} \mathrm{O}$ calculated as described in Eq. (1). The ${ }^{15} \mathrm{~N}_{\text {emitted }}$ excess value was calculated by subtracting the

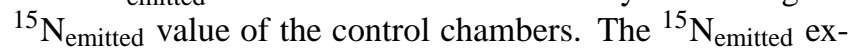
cess value was used to obtain the ${ }^{15} \mathrm{~N}-\mathrm{N}_{2} \mathrm{O}$ excess flux. In case of negative $\mathrm{N}_{2} \mathrm{O}$ fluxes the ${ }^{15} \mathrm{~N}_{\text {emitted }}$ calculation was not applicable since ${ }^{15} \mathrm{~N}-\mathrm{N}_{2} \mathrm{O}$ emissions occurred from labelled soil but could not be quantified because we only measured net $\mathrm{N}_{2} \mathrm{O}$ fluxes. Hence negative $\mathrm{N}_{2} \mathrm{O}$ fluxes were omitted for ${ }^{15} \mathrm{~N}-\mathrm{N}_{2} \mathrm{O}$ flux calculations, which included $35 \%$ of all flux values in the spruce stand and $17 \%$ of those in the beech stand.

\subsection{Recovery of ${ }^{15} \mathrm{~N}$ in $\mathrm{N}_{2} \mathrm{O}$ and $\mathrm{N}_{\mathrm{t}}$}

The recovery of ${ }^{15} \mathrm{~N}$ from the tracers in emitted $\mathrm{N}_{2} \mathrm{O}$ (emission factor) and in soil $\mathrm{N}_{\mathrm{t}}$ was calculated using atom \% values for ${ }^{15} \mathrm{~N}$ mass calculations:

${ }^{15} \mathrm{~N}$ recovery [\%] $=\frac{m^{15} \mathrm{~N}_{\text {rec }}}{m^{15} \mathrm{~N}_{\text {Tracer }}} \cdot 100$

where $m^{15} \mathrm{~N}_{\text {rec }}$ could be $m^{15} \mathrm{~N}_{\mathrm{N}_{2} \mathrm{O}}$ or $m^{15} \mathrm{~N}_{\mathrm{N}_{t}}$, respectively: $m^{15} \mathrm{~N}_{\mathrm{N}_{2} \mathrm{O}}$ is mass of emitted ${ }^{15} \mathrm{~N}-\mathrm{N}_{2} \mathrm{O}$ excess in $\mathrm{mg}{ }^{15} \mathrm{~N} \mathrm{~m}^{-2}$ per time interval considered; $m^{15} \mathrm{~N}_{\mathrm{N}_{t}}$ is mass of ${ }^{15} \mathrm{~N}-\mathrm{N}_{\mathrm{t}}$ excess in $\mathrm{mg}^{15} \mathrm{~N} \mathrm{~m}^{-2}$ after 19 tracer applications. Furthermore, $m^{15} \mathrm{~N}_{\text {Tracer }}$ is mass of ${ }^{15} \mathrm{~N}$ excess in the tracer in $\mathrm{mg}{ }^{15} \mathrm{~N} \mathrm{~m}^{-2}$ applied since the start of the corresponding experiment.

We used two approaches to estimate the mass of emitted ${ }^{15} \mathrm{~N}-\mathrm{N}_{2} \mathrm{O}$ between two consecutive ${ }^{15} \mathrm{~N}-\mathrm{N}_{2} \mathrm{O}$ flux measurements. In the first approach, we used the trapezoid rule. As indicated by the short-term experiment, this approach does not account for the peak emissions during the first week due to the fact that the emissions were measured one week after the application leading potentially to an underestimation of ${ }^{15} \mathrm{~N}-\mathrm{N}_{2} \mathrm{O}$ fluxes whereas fluxes in the time interval between the measurement and the next tracer application were possibly overestimated. We therefore tested a second approach where we assumed that the ${ }^{15} \mathrm{~N}-\mathrm{N}_{2} \mathrm{O}$ fluxes displayed the same temporal trend as observed in the short-term experiment. In this approach, the relative proportion of the tracer emission of one measuring day on the emissions of the time interval between consecutive tracer applications was estimated using the short-term experiment data (Eq. 4).

relative proportion of Ms on Is [-] $=\frac{\operatorname{mean}{ }^{15} \mathrm{~N}-\mathrm{N}_{2} \mathrm{O}_{\mathrm{Ms}}}{\operatorname{mean}^{15} \mathrm{~N}-\mathrm{N}_{2} \mathrm{O}_{\mathrm{Is}}}$

where Ms is a measuring day of the short-term experiment (fluxes for days on which no measurement took place were interpolated from available measured data) and Is is the time interval between two consecutive tracer applications in which the measuring day lies. The mean ${ }^{15} \mathrm{~N}^{-} \mathrm{N}_{2} \mathrm{O}_{\mathrm{Ms}}$ flux (ng ${ }^{15} \mathrm{~N} \mathrm{~m}^{-2} \mathrm{~d}^{-1}$ ) represents the mean excess ${ }^{15} \mathrm{~N}_{-} \mathrm{N}_{2} \mathrm{O}$ flux of all replicates of one labelling treatment of the measuring day of the short-term experiment. The mean ${ }^{15} \mathrm{~N}-\mathrm{N}_{2} \mathrm{O}_{\text {Is }}$ flux (ng ${ }^{15} \mathrm{~N} \mathrm{~m}^{-2}$ interval ${ }^{-1}$ ) represents the cumulative mean excess ${ }^{15} \mathrm{~N}-\mathrm{N}_{2} \mathrm{O}$ flux of all replicates of one labelling treatment of the time interval between two consecutive tracer applications of the short-term experiment. The tracer emission of a measuring day from the one-year experiment was then transformed into the tracer emission of the period between two 
consecutive measurements by dividing it by its relative proportion (Eq. 5).

$$
\begin{aligned}
& \text { cumulative }^{15} \mathrm{~N}_{-\mathrm{N}_{2}} \mathrm{O}_{\mathrm{IL}}\left[\mathrm{ng} \mathrm{m}^{-2} \text { interval }^{-1}\right] \\
& =\frac{{ }^{15} \mathrm{~N}-\mathrm{N}_{2} \mathrm{O}_{\mathrm{ML}}}{\text { relative proportion of Ms on Is }}
\end{aligned}
$$

where cumulative ${ }^{15} \mathrm{~N}-\mathrm{N}_{2} \mathrm{O}_{\text {IL }}$ represents the cumulative excess ${ }^{15} \mathrm{~N}-\mathrm{N}_{2} \mathrm{O}$ flux of a time interval between two consecutive tracer applications of the one-year experiment and ${ }^{15} \mathrm{~N}$ $\mathrm{N}_{2} \mathrm{O}_{\mathrm{ML}}\left(\mathrm{ng}^{15} \mathrm{~N} \mathrm{~m}^{-2} \mathrm{~d}^{-1}\right)$ is the excess ${ }^{15} \mathrm{~N}-\mathrm{N}_{2} \mathrm{O}$ flux of the measuring day in this interval. The relative proportion could only be estimated from the short-term experiment for the $\mathrm{NH}_{4}^{+}$-labelled and $\mathrm{NO}_{3}^{-}$-labelled treatments. Thus, for the $\mathrm{NH}_{4} \mathrm{NO}_{3}$-labelled treatment the mean of both proportions was used. Finally, the annual cumulative excess ${ }^{15} \mathrm{~N}-\mathrm{N}_{2} \mathrm{O}$ flux was calculated by adding up the emissions of all measurement intervals.

Emission factors calculated by the two methods did not show any significant differences for a particular treatment and stand, indicating that the higher values of emissions during the first week of application were balanced by the lower emissions of the following week(s). Therefore, we only report results from the first approach.

Nitrous oxide derived from $\mathrm{N}$ deposition $\left(\mathrm{N}_{2} \mathrm{O}-\mathrm{NDFD}\right)$ was assessed by using the following equation:

$\mathrm{N}_{2} \mathrm{O}-\mathrm{NDFD}\left[\mathrm{kg} \mathrm{ha}^{-1} \mathrm{yr}^{-1}\right]=m \mathrm{~N}_{\mathrm{dep}} \cdot \frac{\mathrm{EF}}{100}$

where $m \mathrm{~N}_{\text {dep }}$ is the mass of inorganic $\mathrm{N}$ of the stand deposition in $\mathrm{kg} \mathrm{ha}^{-1} \mathrm{yr}^{-1}$; $\mathrm{EF}$ is the emission factor (units in \%).

\subsection{Statistical analyses}

Prior to analysis the assumptions of normality of residuals (Shapiro-Wilk or Cramer-von Mises test) and homogeneity of variances (Levene test) were tested. If necessary, we transformed (log and arcsine) data prior to analyses. Two independent sample means were tested for significant differences using the independent Student's t-test, the Welch-test, or the non parametric Mann-Whitney U-test. We used analysis of variance (ANOVA) for comparison of more than two sample means. The weighted harmonic mean was utilised for proportion data with different bases. These proportions were weighted prior to statistical analyses. Temporal pseudoreplication occurred with time series data $\left(\mathrm{N}_{2} \mathrm{O},{ }^{15} \mathrm{~N}-\mathrm{N}_{2} \mathrm{O}\right)$ because measurements were repeatedly done using the same chamber bases. Therefore, we applied linear mixed effects models (Crawley, 2007; Gueorguieva and Krystal, 2004). We set up a basic model including the forest type (beech and spruce) or the different ${ }^{15} \mathrm{~N}$ labelling $\left(\mathrm{NH}_{4}^{+}\right.$-labelled, $\mathrm{NO}_{3}^{-}$labelled, $\mathrm{NH}_{4} \mathrm{NO}_{3}$-labelled) as fixed effects and the spatial replication (individual chamber) nested in time as random effects. The model was extended by a variance function and by a first-order temporal autoregressive function if the extension increased the goodness of the fit of the model. The
Akaike Information Criterion was used to assess the relative goodness of the fit. Simple and multiple regressions were performed using ordinary linear regression models or, if residuals were autocorrelated, generalized least squares extended by an autoregressive moving average function. Autocorrelation was checked with the Durbin-Watson test and by plotting the autocorrelation function. A non-linear leastsquares model was used to estimate parameters of the nonlinear multiple regression. Effects were considered significant if $P \leq 0.05$. In the text results are reported as means \pm 1 standard errors. Statistical analyses were carried out using R 2.10.1 (R Development Core Team, 2009).

\section{Results}

\subsection{Annual $\mathrm{N}_{2} \mathrm{O}$ fluxes}

Fluxes of $\mathrm{N}_{2} \mathrm{O}$ were significantly lower in the spruce stand than in the beech stand $(P<0.0001 ;$ Fig. 1a, b). Cumulative $\mathrm{N}_{2} \mathrm{O}$ emissions were $0.3 \pm 0.1 \mathrm{~kg} \mathrm{Nha}^{-1} \mathrm{yr}^{-1}$ in the spruce stand and $2.6 \pm 0.6 \mathrm{~kg} \mathrm{Nha}^{-1} \mathrm{yr}^{-1}$ in the beech stand. The beech stand displayed a distinct seasonality of $\mathrm{N}_{2} \mathrm{O}$ fluxes with high emissions during the summer months and low emissions during the winter months. Labelling did not increase $\mathrm{N}_{2} \mathrm{O}$ fluxes since we observed no significant differences in $\mathrm{N}_{2} \mathrm{O}$ fluxes between the $\mathrm{NH}_{4}^{+}$-labelled, $\mathrm{NH}_{4} \mathrm{NO}_{3}$ labelled, and the control chambers (data not shown).

\subsection{Short-term ${ }^{15} \mathrm{~N}$ tracer experiment}

In the spruce stand, the application of the $\mathrm{NH}_{4}^{15} \mathrm{NO}_{3}$ tracer caused an immediate and significant increase in ${ }^{15} \mathrm{~N}-\mathrm{N}_{2} \mathrm{O}$ fluxes (Fig. 2a). Subsequently, ${ }^{15} \mathrm{~N}-\mathrm{N}_{2} \mathrm{O}$ emissions decreased again and no significant differences in ${ }^{15} \mathrm{~N}-\mathrm{N}_{2} \mathrm{O}$ fluxes were found three weeks after the $\mathrm{NH}_{4}^{15} \mathrm{NO}_{3}$ tracer application compared to the reference value (pre-measurement at zero hours). Application of the ${ }^{15} \mathrm{NH}_{4} \mathrm{NO}_{3}$ tracer also caused a significant increase in ${ }^{15} \mathrm{~N}-\mathrm{N}_{2} \mathrm{O}$ fluxes $3.5 \mathrm{~h}$ after the addition, but the increase was smaller than in the $\mathrm{NO}_{3}^{-}$labelled plots (Fig. 2a). After one week no significant differences in ${ }^{15} \mathrm{~N}-\mathrm{N}_{2} \mathrm{O}$ fluxes occurred in the $\mathrm{NH}_{4}^{+}$-labelled plots of the spruce stand compared to the reference.

In the beech stand, a similar temporal pattern as in the spruce stand was found after tracer application. In the $\mathrm{NO}_{3}^{-}$labelled plots, we observed an immediate strong and significant increase in ${ }^{15} \mathrm{~N}-\mathrm{N}_{2} \mathrm{O}$ fluxes (Fig. 2b). After one week, ${ }^{15} \mathrm{~N}-\mathrm{N}_{2} \mathrm{O}$ fluxes had decreased and no differences compared to the reference measurement were observed. The application of the ${ }^{15} \mathrm{NH}_{4} \mathrm{NO}_{3}$ tracer only slightly but significantly increased ${ }^{15} \mathrm{~N}-\mathrm{N}_{2} \mathrm{O}$ fluxes and again one week after the tracer addition no significant differences existed when compared to the reference value (Fig. 2b). In both spruce and beech stands, the $\mathrm{NO}_{3}^{-}$-labelled plots displayed three times higher EFs during the first week compared to the $\mathrm{NH}_{4}^{+}$-labelled plots (Table 2). For the first three weeks, the EFs calculated 

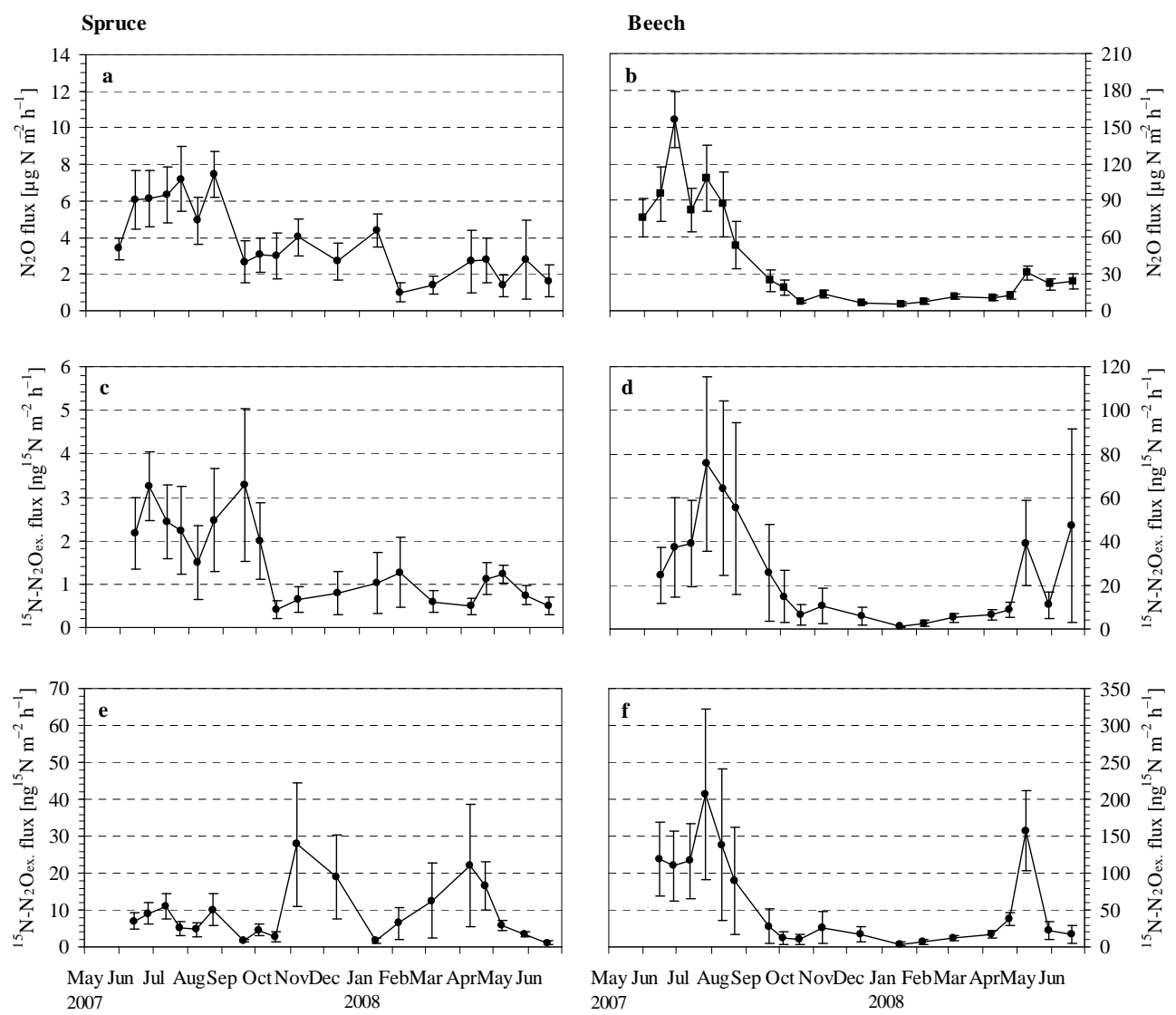

Fig. 1. Mean $( \pm \mathrm{SE}, n=13) \mathrm{N}_{2} \mathrm{O}$ fluxes $(\mathbf{a}, \mathbf{b})$ and mean $( \pm \mathrm{SE}, n=5){ }^{15} \mathrm{~N}-\mathrm{N}_{2} \mathrm{O}$ excess fluxes of the $\mathrm{NH}_{4}^{+}$-labelled treatments $(\mathbf{c}$, d) and $\mathrm{NH}_{4} \mathrm{NO}_{3}$ (double)-labelled treatments $(\mathbf{e}, \mathbf{f})$ of the spruce stand $(\mathbf{a}, \mathbf{c}, \mathbf{e})$ and beech stand $(\mathbf{b}, \mathbf{d}, \mathbf{f})$. Please note the different scales.
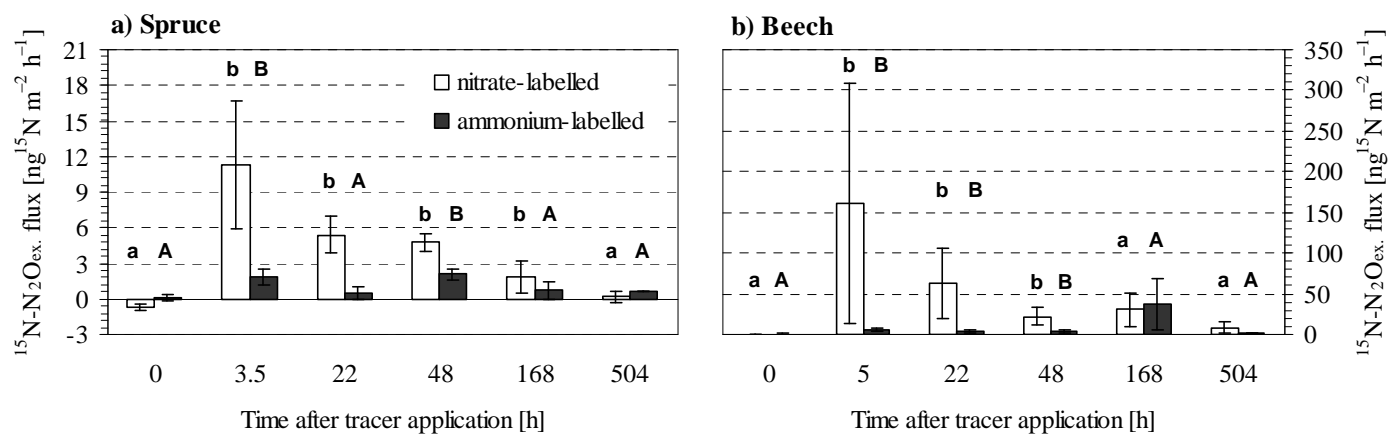

Fig. 2. Mean $( \pm \mathrm{SE}, n=4){ }^{15} \mathrm{~N}-\mathrm{N}_{2} \mathrm{O}$ excess fluxes in the spruce stand (a) and beech stand (b) during the short-term experiment. Fluxes are given for the $\mathrm{NO}_{3}^{-}$-labelled and $\mathrm{NH}_{4}^{+}$-labelled treatments before (zero hours) and after the tracer application. Means followed by the same letter indicated no significant differences in ${ }^{15} \mathrm{~N}-\mathrm{N}_{2} \mathrm{O}$ excess fluxes of one labelling treatment $\left(\mathrm{NO}_{3}^{-}\right.$- or $\mathrm{NH}_{4}^{+}$-labelled) between zero hours and the time points after the tracer application (mixed effects models with linear contrasts at $P \leq 0.05$ ). Please note the different scales.

for the $\mathrm{NO}_{3}^{-}$-labelled plots were approx. three times higher than the EFs calculated for the $\mathrm{NH}_{4}^{+}$-labelled plots as well (Table 2). But in the beech stand, the difference between the EFs of the $\mathrm{NO}_{3}^{-}$-labelled and $\mathrm{NH}_{4}^{+}$-labelled plots decreased and the $\mathrm{EF}$ values of the $\mathrm{NH}_{4}^{+}$-labelled plots were $70 \%$ of the EF values of the $\mathrm{NO}_{3}^{-}$-labelled plots (Table 2).
However, for each stand differences in ${ }^{15} \mathrm{~N}-\mathrm{N}_{2} \mathrm{O}$ emissions between $\mathrm{NH}_{4}^{+}$-labelled chambers and $\mathrm{NO}_{3}^{-}$-labelled chambers were not significant. Moreover, differences in ${ }^{15} \mathrm{~N}$ $\mathrm{N}_{2} \mathrm{O}$ emissions of the $\mathrm{NO}_{3}^{-}$-labelled chambers between both stands were not significant, but ${ }^{15} \mathrm{~N}-\mathrm{N}_{2} \mathrm{O}$ fluxes of the $\mathrm{NH}_{4}^{+}$labelled chambers were significantly higher in the beech stand than in the spruce stand $(P=0.029)$. 
Table 2. Emission factors (EFs) of $\mathrm{N}_{2} \mathrm{O}$ during the first week and the first three weeks following tracer application in the spruce and beech stands. The emission factors were derived from the $\mathrm{NH}_{4}^{+}$-labelled and $\mathrm{NO}_{3}^{-}$-labelled treatments of the short-term experiment $(n=4)$.

\begin{tabular}{lccc|ccc}
\hline & \multicolumn{3}{c|}{$\mathrm{EF}(1$ week) [\%] } & \multicolumn{3}{c}{$\mathrm{EF}(3$ weeks) [\%] } \\
Tracer & $\mathrm{NH}_{4}^{+}$ & $\mathrm{NO}_{3}^{-}$ & $\mathrm{NH}_{4} \mathrm{NO}_{3}^{*}$ & $\mathrm{NH}_{4}^{+}$ & $\mathrm{NO}_{3}^{-}$ & $\mathrm{NH}_{4} \mathrm{NO}_{3}^{*}$ \\
\hline Spruce & $0.01(0.00)$ & $0.03(0.01)$ & $0.02(0.01)$ & $0.02(0.01)$ & $0.05(0.02)$ & $0.04(0.01)$ \\
Beech & $0.12(0.09)$ & $0.31(0.18)$ & $0.22(0.10)$ & $0.43(0.33)$ & $0.62(0.33)$ & $0.54(0.22)$ \\
\hline
\end{tabular}

Means ( $\pm \mathrm{SE})$; no significant differences were detected among stands, labellings, and EFs.

* The EF for the $\mathrm{NH}_{4} \mathrm{NO}_{3}$-labelled treatment was obtained by calculating the mean of the $\mathrm{NH}_{4}^{+}$-labelled and $\mathrm{NO}_{3}^{-}$-labelled treatments of the short-term experiment $(n=8)$.

Table 3. Cumulative $\mathrm{N}_{2} \mathrm{O}$ and ${ }^{15} \mathrm{~N}-\mathrm{N}_{2} \mathrm{O}$ emissions, one-year emission factor (EF), $\mathrm{N}_{2} \mathrm{O}$ derived from deposition ( $\mathrm{N}_{2} \mathrm{O}-\mathrm{NDFD}$ ), ratio of $\mathrm{N}_{2} \mathrm{O}$-NDFD to total $\mathrm{N}_{2} \mathrm{O}$ emissions, and recovery of ${ }^{15} \mathrm{~N}$ tracer in $\mathrm{N}_{\mathrm{t}}$ of the organic layer and the upper $10 \mathrm{~cm}$ of mineral soil. Results are derived from the $\mathrm{NH}_{4}^{+}$-labelled and $\mathrm{NH}_{4} \mathrm{NO}_{3}$-labelled treatments of the one-year experiment.

\begin{tabular}{llcccccc}
\hline & Labelling & $\begin{array}{c}\mathrm{N}_{2} \mathrm{O} \\
{\left[\mathrm{kg} \mathrm{Nha}^{-1} \mathrm{yr}^{-1}\right]}\end{array}$ & $\begin{array}{c}{ }^{15}{\mathrm{~N}-\mathrm{N}_{2} \mathrm{O}}_{\left[{ }^{15} \mathrm{Nha}^{-1} \mathrm{yr}^{-1}\right]} \\
\text { Spruce }\end{array}$ & $\begin{array}{c}\mathrm{EF} \\
{[\%]}\end{array}$ & $\begin{array}{c}\mathrm{N}_{2} \mathrm{O}-\mathrm{NDFD} \\
{\left[\mathrm{g} \mathrm{Nha}^{-1} \mathrm{yr}^{-1}\right]}\end{array}$ & $\begin{array}{c}\mathrm{N}_{2} \mathrm{O}-\mathrm{NDFD} / \\
\mathrm{N}_{2} \mathrm{O}-\mathrm{N}^{*}[\%]\end{array}$ & $\begin{array}{c}\text { Recovery in } \mathrm{N}_{\mathrm{t}} \\
{[\%]}\end{array}$ \\
& $\mathrm{NH}_{4}^{+}$ & $0.26(0.06)^{\mathrm{aA}}$ & $0.12(0.04)^{\mathrm{aA}}$ & $0.03(0.01)^{\mathrm{aA}}$ & $9.4(3.0)^{\mathrm{aA}}$ & $3.6(1.1)^{\mathrm{aA}}$ & $59.2(11.6)^{\mathrm{aA}}$ \\
Beech & $\mathrm{NH}_{4} \mathrm{NO}_{3}$ & $0.30(0.13)^{\mathrm{aA}}$ & $0.91(0.47)^{\mathrm{aB}}$ & $0.12(0.06)^{\mathrm{aA}}$ & $37.9(19.3)^{\mathrm{aA}}$ & $12.5(6.4)^{\mathrm{aA}}$ & $36.6(6.6)^{\mathrm{aA}}$ \\
& $\mathrm{NH}_{4}^{+}$ & $3.15(1.26)^{\mathrm{bA}}$ & $1.79(1.10)^{\mathrm{bA}}$ & $0.46(0.29)^{\mathrm{aA}}$ & $79.6(49.0)^{\mathrm{aA}}$ & $2.5(1.6)^{\mathrm{aA}}$ & $41.7(7.2)^{\mathrm{aA}}$ \\
& $\mathrm{NH}_{4} \mathrm{NO}_{3}$ & $1.75(1.90)^{\mathrm{bA}}$ & $4.28(2.18)^{\mathrm{bA}}$ & $0.58(0.29)^{\mathrm{aA}}$ & $99.3(50.5)^{\mathrm{aA}}$ & $5.7(2.9)^{\mathrm{aA}}$ & $20.7(3.1)^{\mathrm{aB}}$ \\
\hline
\end{tabular}

Means $\left( \pm \mathrm{SE} ; n=5\right.$ for $\mathrm{N}_{2} \mathrm{O},{ }^{15} \mathrm{~N}-\mathrm{N}_{2} \mathrm{O}, \mathrm{EF}, \mathrm{N}_{2} \mathrm{O}-\mathrm{NDFD}$, and $\mathrm{N}_{2} \mathrm{O}-\mathrm{NDFD} / \mathrm{N}_{2} \mathrm{O}-\mathrm{N}$ and $n=4$ for recovery in $\mathrm{N}_{\mathrm{t}}$ ) followed by the same lower-case letters indicated no significant differences among both stands and the same labelling treatments. Means followed by the same capital letters indicated no significant differences among different labelling treatments within one stand (independent t-test at $P \leq 0.05$ ).

* The ratio $\mathrm{N}_{2} \mathrm{O}-\mathrm{NDFD} / \mathrm{N}_{2} \mathrm{O}-\mathrm{N}$ represented the weighted harmonic mean with corresponding SE.

Within one stand, fluxes of total $\mathrm{N}_{2} \mathrm{O}$ were not significantly different in time during the short-term experiment and were 10-times higher in the beech stand $\left(22.8 \pm 3.6 \mu \mathrm{g} \mathrm{N} \mathrm{m}^{-2} \mathrm{~h}^{-1}\right)$ than in the spruce stand $\left(2.2 \pm 0.5 \mu \mathrm{g} \mathrm{N} \mathrm{m}{ }^{-2} \mathrm{~h}^{-1} ; P=0.009\right)$. Since no changes were observed in fluxes we assumed that total $\mathrm{N}_{2} \mathrm{O}$ fluxes were not changed by the tracer application. The same was true for the contents of $\mathrm{NH}_{4}^{+}, \mathrm{NO}_{3}^{-}$and soil moisture, which remained unchanged during the period of the short-term experiment.

\subsection{One-year ${ }^{15} \mathrm{~N}$ tracer experiment}

In the spruce stand, fluxes of ${ }^{15} \mathrm{~N}-\mathrm{N}_{2} \mathrm{O}$ were significantly higher in the $\mathrm{NH}_{4} \mathrm{NO}_{3}$-labelled treatment than in the $\mathrm{NH}_{4}^{+}$labelled treatment $(P=0.0014)$, though $\mathrm{N}_{2} \mathrm{O}$ fluxes were not significantly different between the two labelled treatments (Fig. 1a, c, e, Table 3). Fluxes of ${ }^{15} \mathrm{~N}^{-N_{2}} \mathrm{O}$ and $\mathrm{N}_{2} \mathrm{O}$ were positively correlated for both labellings individually $(P \leq 0.05)$. Emissions of ${ }^{15} \mathrm{~N}-\mathrm{N}_{2} \mathrm{O}$ of the $\mathrm{NH}_{4} \mathrm{NO}_{3}$ labelled treatment displayed high variability especially during the winter months when nitrate availability was low and any addition of nitrate with the $\mathrm{NH}_{4} \mathrm{NO}_{3}$ treatment may have contributed significantly to the ${ }^{15} \mathrm{~N}-\mathrm{N}_{2} \mathrm{O}$ fluxes in the spruce stand (Fig. 1e). We did not observe continuous enrichment of ${ }^{15} \mathrm{~N}$ in $\mathrm{N}_{2} \mathrm{O}$ during the one-year experiment. The mean annual fraction of ${ }^{15} \mathrm{~N}-\mathrm{N}_{2} \mathrm{O}$ on total $\mathrm{N}_{2} \mathrm{O}-\mathrm{N}$ was $0.04 \%(0.00-$
$0.22 \%)$ for the $\mathrm{NH}_{4}^{+}$-labelled treatment and $0.21 \%(0.01-$ $0.71 \%$ ) for the $\mathrm{NH}_{4} \mathrm{NO}_{3}$-labelled treatment. In the beech stand, we observed no significant differences in ${ }^{15} \mathrm{~N}-\mathrm{N}_{2} \mathrm{O}$ fluxes between both treatments and beginning in July (1.5 months after the first labelling event), they followed a similar seasonal trend as the total $\mathrm{N}_{2} \mathrm{O}$ flux in both treatments (Fig. 1b, d, f, Table 3). Fluxes of ${ }^{15} \mathrm{~N}-\mathrm{N}_{2} \mathrm{O}$ and $\mathrm{N}_{2} \mathrm{O}$ displayed strong correlations for both treatments $(P \leq 0.0001)$. The fraction of ${ }^{15} \mathrm{~N}-\mathrm{N}_{2} \mathrm{O}$ on $\mathrm{N}_{2} \mathrm{O}-\mathrm{N}$ averages $0.06 \%(0.00-$ $0.22 \%)$ for the $\mathrm{NH}_{4}^{+}$-labelled treatment and $0.19 \%(0.04$ $0.49 \%$ ) for the $\mathrm{NH}_{4} \mathrm{NO}_{3}$-labelled treatment. In both treatments ${ }^{15} \mathrm{~N}-\mathrm{N}_{2} \mathrm{O}$ emissions were significantly higher in the deciduous stand than in the coniferous stand $(P \leq 0.05$; Table 3).

Using the EF values approx. $0.12 \%$ (spruce) to $0.58 \%$ (beech) of the inorganic throughfall $\mathrm{N}$ deposition was lost as $\mathrm{N}_{2} \mathrm{O}$ within one year, which corresponded to $12.5 \%$ (spruce) and $5.7 \%$ (beech) of the total annual $\mathrm{N}_{2} \mathrm{O}$ emissions $\left(\mathrm{N}_{2} \mathrm{O}-\right.$ $\mathrm{NDFD} / \mathrm{N}_{2} \mathrm{O}-\mathrm{N}$, Table 3). For the spruce stand, the EFs of the first week and first three weeks were significantly lower than the EF of one year $(P=0.03)$ but no significant differences among EFs were found for the beech stand (Tables 2, 3).

We recovered a large fraction of 59\% (spruce) and $42 \%$ (beech) of the applied $\mathrm{NH}_{4}^{+}$in $\mathrm{N}_{\mathrm{t}}$ of the organic layer and the surface $10 \mathrm{~cm}$ of the mineral soil (Table 3 ). In contrast, the recovery of $\mathrm{NO}_{3}^{-}$tracer in $\mathrm{N}_{\mathrm{t}}$ of the $\mathrm{NH}_{4} \mathrm{NO}_{3}$-treatment 


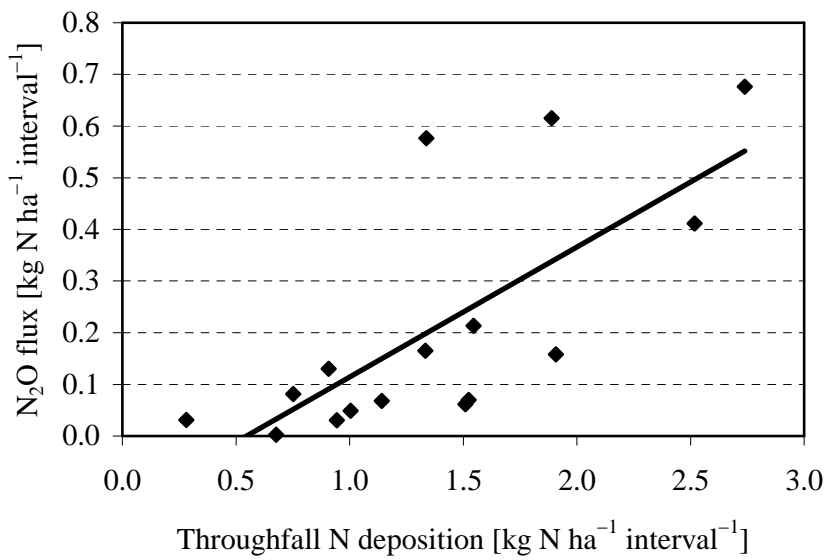

Fig. 3. Relationship between $\mathrm{N}_{2} \mathrm{O}$ fluxes $(y)$ and total throughfall $\mathrm{N}$ depositions $(x)$ in the beech stand from May 2007 to June 2008 ( $y=$ $\left.x \cdot 0.25( \pm 0.06)-0.14( \pm 0.09) ; r^{2}=0.53, P=0.001, d f=14\right)$.

(obtained by subtracting the recovery in the $\mathrm{NH}_{4}^{+}$treatment) was negligible in the beech stand and less than $10 \%$ in the spruce stand.

\subsection{Relationship of $\mathrm{N}_{2} \mathrm{O}$ flux rates to throughfall $\mathrm{N}$ depositions}

In the beech stand, $\mathrm{N}_{2} \mathrm{O}$ fluxes were positively correlated with total throughfall $\mathrm{N}$ depositions $(P=0.001$; Fig. 3, Table 4) and with $\mathrm{NH}_{4}^{+}-\mathrm{N}$ depositions $(P=0.001$; Table 4). The slope of the regression equation, which described the modelled relationship between measured $\mathrm{N}_{2} \mathrm{O}$ fluxes and measured $\mathrm{N}$ depositions, indicated the fraction of throughfall $\mathrm{N}$ deposition emitted as $\mathrm{N}_{2} \mathrm{O}$. The fraction was $25 \%$. However, both $\mathrm{N}_{2} \mathrm{O}$ fluxes $(P<0.0001$; Fig. 4$)$ and throughfall $\mathrm{N}$ deposition were also positively related with soil temperature $(\mathrm{N}$ deposition $=$ temperature $\cdot 0.09( \pm 0.03)+0.70( \pm 0.27)$, $\left.r^{2}=0.37, P=0.01, d f=14\right)$. When soil temperature was included in the regression equation the calculated EF was reduced from $25 \%$ to $8.6 \%$ (Fig. 4). Throughfall deposition was further positively correlated with precipitation ( $P=0.004$; not shown). For the spruce stand, we did not observe significant correlations between $\mathrm{N}_{2} \mathrm{O}$ fluxes with $\mathrm{N}$ depositions. However $\mathrm{N}_{2} \mathrm{O}$ fluxes were positively correlated with precipitation (Table 4).

We also calculated EFs according to the fraction method, where EFs are calculated by relating measured total $\mathrm{N}_{2} \mathrm{O}$ emissions to measured $\mathrm{N}$ depositions (for the calculation see notes of Table 5). The EFs obtained from this approach were $0.9 \%$ for the spruce stand and $13 \%$ for the beech stand.

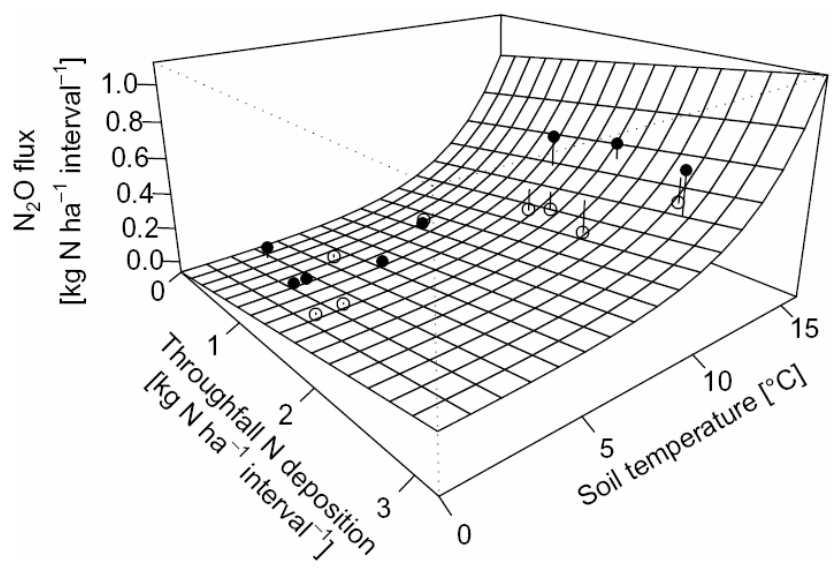

Fig. 4. Relationship of $\mathrm{N}_{2} \mathrm{O}$ fluxes $(y)$ to throughfall $\mathrm{N}$ depositions $(x 1)$ and soil temperatures in $5 \mathrm{~cm}$ soil depth $(x 2)(y=0.086$ $( \pm 0.063) \cdot x 1+0.001( \pm 0.000) \cdot \exp (0.468( \pm 0.242) \cdot x 2)-0.042$ $\left.( \pm 0.073) ; r^{2}=0.78, P<0.0001, d f=13\right)$. The measured data are indicated as points, where black points are located above the surface area and white points are located below the surface area. The solid lines indicate the deviations of measured data from the model.

\section{Discussion}

\subsection{Annual $\mathrm{N}_{2} \mathrm{O}$ fluxes}

The relatively low $\mathrm{N}_{2} \mathrm{O}$ fluxes from the spruce stand and the higher $\mathrm{N}_{2} \mathrm{O}$ fluxes from the beech stand were within the range of $\mathrm{N}_{2} \mathrm{O}$ emissions reported for other temperate coniferous and deciduous forests (Butterbach-Bahl et al., 2001; Macdonald et al., 1997; Oura et al., 2001; ZechmeisterBoltenstern, 2002; see also Table 5). The compiled values from literature (Table 5) further support the observation that deciduous forests generally tend to be a higher source for $\mathrm{N}_{2} \mathrm{O}\left(>20 \mu \mathrm{g} \mathrm{N} \mathrm{N}_{2} \mathrm{O}-\mathrm{N} \mathrm{m}^{-2} \mathrm{~h}^{-1}\right)$ than coniferous forests $\left(<10 \mu \mathrm{g} \mathrm{N}_{2} \mathrm{O}-\mathrm{N} \mathrm{m}^{-2} \mathrm{~h}^{-1}\right)$. We attributed the differences in $\mathrm{N}_{2} \mathrm{O}$ fluxes between the investigated forest types to the differences in the structure and quality of the litter (e.g. pH, $\mathrm{C} / \mathrm{N}$ ratio; see Table 1). The laminar structure of the beech litter on the surface of the moder type humus may have reduced gas diffusivity, whereas the needle litter of spruce may have created a well-aerated organic layer as was reported by Ball et al. (1997) for the Solling sites. As a result, the high $\mathrm{N}_{2} \mathrm{O}$ emissions during the summer months were possibly produced by denitrification in anaerobic micro-sites in the soil due to high oxygen consumption by microorganisms and plants during high summer temperatures (Brumme et al., 1999). Wolf and Brumme (2002) identified denitrification as main process for $\mathrm{N}_{2} \mathrm{O}$ production in the same beech stand which was investigated in the present study.

Net uptake of $\mathrm{N}_{2} \mathrm{O}$, as we observed in single chambers, may be ascribed to consumption of $\mathrm{N}_{2} \mathrm{O}$ during denitrification to $\mathrm{N}_{2}$ (Kroeze et al., 2007). The review by Kroeze et al. (2007) revealed that uptake of $\mathrm{N}_{2} \mathrm{O}$ may occur at low 
Table 4. Results of the regression analyses of $\mathrm{N}_{2} \mathrm{O}-\mathrm{N}$ fluxes and throughfall $\mathrm{N}$ depositions (total $\mathrm{N}, \mathrm{NH}_{4}^{+}-\mathrm{N}, \mathrm{NO}_{3}^{-}-\mathrm{N}$, and organic $\mathrm{N}$ depositions) and precipitation.

\begin{tabular}{|c|c|c|c|c|c|c|c|c|c|c|c|c|c|c|c|}
\hline & \multicolumn{3}{|c|}{$\mathrm{N}_{\text {total }}$} & \multicolumn{3}{|c|}{$\mathrm{NH}_{4}^{+}-\mathrm{N}$} & \multicolumn{3}{|c|}{$\mathrm{NO}_{3}^{-}-\mathrm{N}$} & \multicolumn{3}{|c|}{$\mathrm{N}_{\text {org }}$} & \multicolumn{3}{|c|}{ Precipitation } \\
\hline & $r^{2}$ & $P$ & $d f$ & $r^{2}$ & $P$ & $d f$ & $r^{2}$ & $\stackrel{3}{P}$ & $d f$ & $r^{2}$ & $P$ & $d f$ & $r^{2}$ & $P$ & $d f$ \\
\hline Spruce & - & ns & - & - & ns & - & - & ns & - & - & ns & - & 0.30 & 0.042 & 12 \\
\hline Beech & 0.53 & 0.001 & 14 & 0.53 & 0.001 & 14 & - & ns & - & - & ns & - & - & ns & - \\
\hline
\end{tabular}

ns is not significant.

oxygen and $\mathrm{NO}_{3}^{-}$availability, even at fertilised sites, and that sites with small $\mathrm{N}_{2} \mathrm{O}$ fluxes may change from sources to sinks depending on the soil conditions. At the beech stand, negative $\mathrm{N}_{2} \mathrm{O}$ fluxes were almost exclusively measured during the winter months where soil moisture was high and soil $\mathrm{NO}_{3}^{-}$concentrations were close to zero.

\subsection{Temporal dynamics of $\mathrm{N}_{2} \mathrm{O}$ emissions derived from $\mathrm{N}$ deposition}

The immediate increase in ${ }^{15} \mathrm{~N}-\mathrm{N}_{2} \mathrm{O}$ fluxes that occurred within 3.5-5 $\mathrm{h}$ in the short-term experiment after $\mathrm{NH}_{4}^{15} \mathrm{NO}_{3}$ and ${ }^{15} \mathrm{NH}_{4} \mathrm{NO}_{3}$ tracer application indicates that deposited $\mathrm{N}$ contributed promptly to $\mathrm{N}_{2} \mathrm{O}$ production. However, the contribution of $\mathrm{N}$ deposition to $\mathrm{N}_{2} \mathrm{O}$ fluxes decreased within the following three weeks. In the spruce stand release of $\mathrm{N}_{2} \mathrm{O}$ derived from the ${ }^{15} \mathrm{~N}$ label occurred over a longer period than in the beech stand, where loss of deposited $\mathrm{N}$ as $\mathrm{N}_{2} \mathrm{O}$ occurred entirely during the first three weeks. This short-lived increase in ${ }^{15} \mathrm{~N}-\mathrm{N}_{2} \mathrm{O}$ emissions, which lasted approx. three weeks, was probably related to biotic and abiotic immobilisation of added $\mathrm{N}$ and to dilution processes. In contrast to our hypotheses, the repeated application of ${ }^{15} \mathrm{~N}$ labelled $\mathrm{N}$ did not lead to any further increase in ${ }^{15} \mathrm{~N}$ enrichment of $\mathrm{N}_{2} \mathrm{O}$ emitted during the one-year experiment. This indicates that the main effect of $\mathrm{N}$ deposition on $\mathrm{N}_{2} \mathrm{O}$ fluxes occurs when the mineral $\mathrm{N}$ enters the soil system ("short-lived effects"). The absence of "medium-term" effect (up to one year) may be explained by continual immobilisation of $\mathrm{N}$ during the related additions and by the lack of any remobilisation of the immobilised $\mathrm{N}$. Our recovery of $\mathrm{NH}_{4} \mathrm{NO}_{3}$ tracer in soil $\mathrm{N}_{\mathrm{t}}$ also showed that a great proportion of $\mathrm{N}$ deposition was retained in the soil. Our finding was supported by output analysis by Brumme and Khanna (2009b) and Feng et al. (2008), which indicated that in both systems (spruce and beech) the deposited $\mathrm{N}$ was predominantly retained despite the amount of $\mathrm{N}$ deposition was in excess of that required for plant increment.

\subsection{Processes of $\mathrm{N}_{2} \mathrm{O}$ emissions derived from $\mathrm{N}$ deposition}

The greater increase in ${ }^{15} \mathrm{~N}-\mathrm{N}_{2} \mathrm{O}$ fluxes after $\mathrm{NO}_{3}^{-}$tracer application than after $\mathrm{NH}_{4}^{+}$tracer application suggests that den- itrification was the dominant process for the input-derived emissions at both sites. Water addition probably created additional anaerobic micro-sites resulting in favourable conditions for denitrification, which mimics conditions when natural wet $\mathrm{N}$ deposition occurs. Denitrification was also found to be the dominant process at our beech stand at the Solling site by Wolf and Brumme (2002). The smaller ${ }^{15} \mathrm{~N}-\mathrm{N}_{2} \mathrm{O}$ flux increase after ${ }^{15} \mathrm{NH}_{4} \mathrm{NO}_{3}$ tracer application was probably caused by low activity of nitrifiers in these acid soils and the weak competition of nitrifiers for available $\mathrm{NH}_{4}^{+}$(Corre and Lamersdorf, 2004 (study conducted at Solling); Rennenberg et al., 1998). Fertilisation with $\left(\mathrm{NH}_{4}\right)_{2} \mathrm{SO}_{4}$ also delayed an increase in $\mathrm{N}_{2} \mathrm{O}$ emissions by 14 days at our beech stand (Brumme and Beese, 1992), indicating low activity of nitrifiers and thus a delay of denitrification. In contrast, rapid increases in $\mathrm{N}_{2} \mathrm{O}$ fluxes have been reported after fertilisation with $\mathrm{NO}_{3}^{-}$-containing fertilisers of coniferous forests (Klemedtsson et al., 1997; Macdonald et al., 1997; Sitaula et al., 1995).

For both stands, the fraction of ${ }^{15} \mathrm{~N}-\mathrm{N}_{2} \mathrm{O}$ on $\mathrm{N}_{2} \mathrm{O}-\mathrm{N}$ of $0.05 \%$ for the $\mathrm{NH}_{4}^{+}$-labelled treatment and of $0.20 \%$ for the $\mathrm{NH}_{4} \mathrm{NO}_{3}$-labelled treatment of the one-year experiment suggests that the contribution of $\mathrm{NH}_{4}^{+}$to $\mathrm{N}_{2} \mathrm{O}$ emissions was $25 \%$ and of $\mathrm{NO}_{3}^{-} 75 \%$. Similar results were presented by Ambus et al. (2006) who showed that $62 \%$ of $\mathrm{N}_{2} \mathrm{O}$ emissions in 11 European forests were derived from $\mathrm{NO}_{3}^{-}$and $34 \%$ were derived from $\mathrm{NH}_{4}^{+}$.

\subsection{Contribution of $\mathrm{N}$ deposition to $\mathrm{N}_{2} \mathrm{O}$ emissions}

The compilation of published studies on this subject showed a huge range of results for the impact of $\mathrm{N}$ input on $\mathrm{N}_{2} \mathrm{O}$ fluxes in temperate forests similar as we found in our study (Table 5). Our study indicated that the emission factor (EF) depended on the method used for its calculation. The $E F_{R}$ value of $25 \%$ for our beech stand, which was calculated by using the regression method, was higher than the $\mathrm{EF}_{\mathrm{F}}$ values, which were obtained by the fraction method and ranged from $0.9 \%$ (spruce) to $13 \%$ (beech). The $\mathrm{EF}_{\mathrm{R}}$ and $\mathrm{EF}_{\mathrm{F}}$ were again both higher than the $\mathrm{EF}^{15} \mathrm{~N}$ values derived from our ${ }^{15} \mathrm{~N}$ tracer study $(0.1 \%$ for spruce and $0.6 \%$ for beech stands). Further, a $\mathrm{EF}_{\mathrm{FB}}$ value (obtained from $\mathrm{N}$ fertilisation experiments; for calculations see notes of Table 5) of $1.6 \%$ was calculated for 
Table 5. Compilation of published studies that investigated the impact of $\mathrm{N}$ input on $\mathrm{N}_{2} \mathrm{O}$ fluxes from deciduous and coniferous temperate forest soils. Studies are divided into fertilisation, deposition, and ${ }^{15} \mathrm{~N}$ tracer experiments. The emission factor (EF) for $\mathrm{N}_{2} \mathrm{O}$ is given for one year if not differently indicated.

\begin{tabular}{|c|c|c|c|c|c|c|}
\hline Forest type & Type of $\mathrm{N}$ input & $\begin{array}{l}\mathrm{N}_{2} \mathrm{O} \\
{\left[\mu \mathrm{g} \mathrm{N} \mathrm{m}^{-2} \mathrm{~h}^{-1}\right]}\end{array}$ & $\begin{array}{l}\text { Emission } \\
\text { factor [\%] }\end{array}$ & $\begin{array}{l}\text { Method } \\
\text { used }\end{array}$ & Treatment & Reference \\
\hline \multirow[t]{20}{*}{ Deciduous } & \multirow[t]{8}{*}{ Fertilisation } & 0.68 & $0.03^{\mathrm{e}}$ & $\mathrm{EF}_{\mathrm{FB}}$ & $\begin{array}{l}\mathrm{NH}_{4} \mathrm{NO}_{3} \text {-fertilised }(120(1 . \mathrm{yr}) \text { and } 150 \\
\text { (2. yr) } \mathrm{kg} \mathrm{N}^{-1} \mathrm{yr}^{-1} ; \text { chronic } \mathrm{N} \text { addition } \\
\text { exp.; measurement in the } 2 . \mathrm{yr} \text {; USA) }\end{array}$ & Bowden et al. (1991) \\
\hline & & 0.57 & $0.06^{\mathrm{e}}$ & $\mathrm{EF}_{\mathrm{FB}}$ & $\begin{array}{l}\mathrm{NH}_{4} \mathrm{NO}_{3} \text {-fertilised ( } 37 \text { (1. yr) and } 50 \\
\left(2 . \mathrm{yr}^{2} \mathrm{~kg} \mathrm{Nha}^{-1} \mathrm{yr}^{-1} \text {; chronic } \mathrm{N} \text { addition exp.; }\right. \\
\text { measurement in the } 2 . \mathrm{yr} \text {; USA })\end{array}$ & \\
\hline & & 0.23 & & & Unfertilised (USA) & \\
\hline & & 89 & 1.6 & $\mathrm{EF}_{\mathrm{FB}}$ & $\begin{array}{l}\left(\mathrm{NH}_{4}\right)_{2} \mathrm{SO}_{4} \text {-fertilised }\left(140 \mathrm{~kg} \mathrm{~N} \mathrm{ha}^{-1} \mathrm{yr}^{-1} \text {; }\right. \\
\text { chronic } \mathrm{N} \text { addition exp.; } \\
\text { measurement in the } 6 . \text { and } 7 . \mathrm{yr} \text {; Germany) }\end{array}$ & Brumme and Beese (1992) \\
\hline & & 64 & $16^{\mathrm{e}}$ & $\mathrm{EF}_{\mathrm{F}}$ & $\begin{array}{l}\text { Unfertilised ( } 35 \mathrm{~kg} \mathrm{~N} \mathrm{ha}^{-1} \mathrm{yr}^{-1} \text { deposition; } \\
\text { Germany) }\end{array}$ & \\
\hline & & $<10$ & $<0.3$ & $\mathrm{EF}_{\mathrm{F}}$ & $\begin{array}{l}\mathrm{NH}_{4} \mathrm{NO}_{3} \text {-fertilised }\left(150 \mathrm{~kg} \mathrm{Nha}^{-1} \mathrm{yr}^{-1} ;\right. \\
\text { chronic } \mathrm{N} \text { addition exp.; measurement in the } \\
\text { 13. yr; USA) }\end{array}$ & Venterea et al. (2003) \\
\hline & & $<10$ & $<0.3$ & $\mathrm{EF}_{\mathrm{F}}$ & $\begin{array}{l}\mathrm{NH}_{4} \mathrm{NO}_{3} \text {-fertilised }\left(50 \mathrm{~kg} \mathrm{Nha}^{-1} \mathrm{yr}^{-1} \text {; chronic }\right. \\
\mathrm{N} \text { addition exp.; measurement in the } 13 \text {. yr; } \\
\text { USA) }\end{array}$ & \\
\hline & & $<10$ & $<0.3$ & $\mathrm{EF}_{\mathrm{F}}$ & $\begin{array}{l}\text { Unfertilised ( } 8 \mathrm{~kg} \mathrm{Nha}^{-1} \mathrm{yr}^{-1} \text { wet }+ \text { dry } \\
\text { deposition; USA) }\end{array}$ & \\
\hline & \multirow[t]{11}{*}{ Deposition } & 5.7 & $2^{\mathrm{e}}$ & $\mathrm{EF}_{\mathrm{F}}$ & $\begin{array}{l}25.6 \mathrm{~kg} \mathrm{~N} \mathrm{ha}^{-1} \mathrm{yr}^{-1} \text { throughfall + stemflow dep. } \\
\text { (Denmark) }\end{array}$ & Beier et al. (2001) \\
\hline & & 83.3 & $22^{\mathrm{e}}$ & $\mathrm{EF}_{\mathrm{F}}$ & $33 \mathrm{~kg} \mathrm{Nha}^{-1} \mathrm{yr}^{-1}$ wet deposition (Germany) & \multirow[t]{5}{*}{ Brumme et al. (1999) } \\
\hline & & 9.1 & $2.4^{\mathrm{e}}$ & $\mathrm{EF}_{\mathrm{F}}$ & $33 \mathrm{~kg} \mathrm{~N} \mathrm{ha}^{-1} \mathrm{yr}^{-1}$ wet deposition (Germany) & \\
\hline & & 1.9 & $0.6^{\mathrm{e}}$ & $\mathrm{EF}_{\mathrm{F}}$ & $\begin{array}{l}28 \mathrm{~kg} \mathrm{Nha}^{-1} \mathrm{yr}^{-1} \text { throughfall deposition } \\
\text { (Germany) }\end{array}$ & \\
\hline & & 7.2 & $2.4^{\mathrm{e}}$ & $\mathrm{EF}_{\mathrm{F}}$ & $\begin{array}{l}26 \mathrm{~kg} \mathrm{Nha}^{-1} \mathrm{yr}^{-1} \text { throughfall deposition } \\
\text { (Germany) }\end{array}$ & \\
\hline & & 4.7 & $1.9^{\mathrm{e}}$ & $\mathrm{EF}_{\mathrm{F}}$ & $\begin{array}{l}21 \mathrm{~kg} \mathrm{Nha}^{-1} \mathrm{yr}^{-1} \text { throughfall deposition } \\
\text { (Germany) }\end{array}$ & \\
\hline & & $7.3-9.0$ & $\sim 3.5^{\mathrm{e}}$ & $\mathrm{EF}_{\mathrm{F}}$ & $20.2 \mathrm{~kg} \mathrm{Nha}^{-1} \mathrm{yr}^{-1}$ wet deposition (Austria) & \multirow[t]{2}{*}{ Kitzler et al. $(2006 \mathrm{a})^{\mathrm{a}}$} \\
\hline & & $5.9-7.4$ & $\sim 4.6^{\mathrm{e}}$ & $\mathrm{EF}_{\mathrm{F}}$ & $12.6 \mathrm{~kg} \mathrm{Nha}^{-1} \mathrm{yr}^{-1}$ wet deposition (Austria) & \\
\hline & & 2.3 & 1.27 & $\mathrm{EF}_{\mathrm{F}}$ & $\begin{array}{l}15.7 \mathrm{~kg} \mathrm{~N} \mathrm{ha}^{-1} \mathrm{yr}^{-1} \text { throughfall deposition } \\
\text { (Japan) }\end{array}$ & Oura et al. (2001) \\
\hline & & 58.4 & 10 & $\mathrm{EF}_{\mathrm{R}}$ & $20 \mathrm{~kg} \mathrm{~N} \mathrm{ha}^{-1} \mathrm{yr}^{-1}$ wet deposition (Germany) & Papen and Butterbach-Bahl (1999) \\
\hline & & 29.7 & $25 ; 13$ & $\mathrm{EF}_{\mathrm{R}}, \mathrm{EF}_{\mathrm{F}}$ & $\begin{array}{l}20 \mathrm{~kg} \mathrm{Nha}^{-1} \mathrm{yr}^{-1} \text { throughfall }+ \text { stemflow dep. } \\
\text { (Germany) }\end{array}$ & This study \\
\hline & ${ }^{15} \mathrm{~N}$ tracer & 29.7 & 0.6 & $\mathrm{EF}_{15} \mathrm{~N}$ & $\begin{array}{l}20 \mathrm{~kg} \mathrm{Nha}^{-1} \mathrm{yr}^{-1} \text { throughfall }+ \text { stemflow dep. } \\
\text { (Germany) }\end{array}$ & This study \\
\hline
\end{tabular}

a long-term fertilisation experiment at our beech stand where $140 \mathrm{~kg} \mathrm{Nha}^{-1} \mathrm{yr}^{-1}$ were applied over a 5-6 yr period (Table 5; Brumme and Beese, 1992).

In literature $\mathrm{EF}_{\mathrm{R}}$ values were among the highest reported. For example, a study in southern Germany reported an $\mathrm{EF}_{\mathrm{R}}$ of $10 \%$ for a beech stand $\left(5.1 \mathrm{~kg} \mathrm{~N}_{2} \mathrm{O}-\mathrm{N} \mathrm{ha}^{-1} \mathrm{yr}^{-1}\right)$ and $0.5 \%$ for a spruce stand $\left(1.4 \mathrm{~kg} \mathrm{~N}_{2} \mathrm{O}-\mathrm{N} \mathrm{ha}^{-1} \mathrm{yr}^{-1}\right)$ using the regression approach (Papen and Butterbach-Bahl, 1999; Table 5). Denier van der Gon and Bleeker (2005) combined results from several studies conducted in temperate forests and found an $\mathrm{EF}_{\mathrm{R}}$ value of $6.3 \%$ for deciduous forests and of $1.4 \%$ for coniferous forests. A positive correlation of $\mathrm{N}_{2} \mathrm{O}+$ $\mathrm{NO}$ fluxes with $\mathrm{N}$ deposition was also reported for 15 European forests exposed to different rates of $\mathrm{N}$ deposition where between $2 \%$ and $32 \%$ of total $\mathrm{N}$ deposition were emitted as $\mathrm{N}_{2} \mathrm{O}+\mathrm{NO}$ (Pilegaard et al., 2006). Emission factors $\mathrm{EF}_{\mathrm{F}}$ show a wide range from $<0.1 \%$ to $22 \%$ for both forest types (Table 5). Using the fraction method, Denier van der Gon and Bleeker (2005) found an average $\mathrm{EF}_{\mathrm{F}}$ of $2.4 \%$ for coniferous forests and of $6.5 \%$ for deciduous forests. The $\mathrm{EF}_{\mathrm{FB}}$ based on fertilised plots ranged from $0.1 \%$ to $0.9 \%$ for the coniferous forests and from $0.03 \%$ to $1.6 \%$ for the deciduous forests (Table 5). The results of EF estimations can be summarised as follows:

$\mathrm{EF}_{15 \mathrm{~N}} \approx \mathrm{EF}_{\mathrm{FB}} \ll \mathrm{EF}_{\mathrm{F}} \approx \mathrm{EF}_{\mathrm{R}}$

What factors cause the large differences in EFs when calculated employing different methods? The fraction of $\mathrm{N}_{2} \mathrm{O}$ derived from inorganic $\mathrm{N}$ deposition was relatively small (13\% on spruce and $6 \%$ on beech stands) indicating that sources other than direct $\mathrm{N}$ deposition were involved in $\mathrm{N}_{2} \mathrm{O}$ emissions. The $\mathrm{EF}_{\mathrm{FB}}$ considers such background emissions 
Table 5. Continued.

\begin{tabular}{|c|c|c|c|c|c|c|}
\hline Forest type & Type of $\mathrm{N}$ input & $\begin{array}{l}\mathrm{N}_{2} \mathrm{O} \\
{\left[\mu \mathrm{g} \mathrm{N} \mathrm{m}^{-2} \mathrm{~h}^{-1}\right]}\end{array}$ & $\begin{array}{l}\text { Emission } \\
\text { factor [\%] }\end{array}$ & $\begin{array}{l}\text { Method } \\
\text { used }\end{array}$ & Treatment & Reference \\
\hline \multirow[t]{18}{*}{ Coniferous } & Fertilisation & 4.0 & $0.1^{\mathrm{e}}$ & $\mathrm{EF}_{\mathrm{FB}}$ & $\begin{array}{l}\mathrm{NH}_{4} \mathrm{NO}_{3} \text {-fertilised }(120(1 . \mathrm{yr}) \text { and } 150 \\
(2 . \mathrm{yr}) \mathrm{kg} \mathrm{Nha}^{-1} \mathrm{yr}^{-1} \text {; chronic } \mathrm{N} \text { addi- } \\
\text { tion exp.; measurement in the } 2 . \mathrm{yr} \text {; USA) }\end{array}$ & Bowden et al. (1991) \\
\hline & & 3.0 & $0.5^{\mathrm{e}}$ & $\mathrm{EF}_{\mathrm{FB}}$ & $\begin{array}{l}\mathrm{NH}_{4} \mathrm{NO}_{3} \text {-fertilised ( } 37(1 . \mathrm{yr}) \text { and } 50 \\
(2 . \mathrm{yr}) \mathrm{kg} \mathrm{Nha}^{-1} \mathrm{yr}^{-1} \text {; chronic } \mathrm{N} \text { addi- } \\
\text { tion exp.; measurement in the } 2 . \mathrm{yr} \text {; USA) }\end{array}$ & \\
\hline & & 0.8 & & & Unfertilised (USA) & \\
\hline & & 3.11 & 0.35 & $\mathrm{EF}_{\mathrm{F}}$ & $\begin{array}{l}\mathrm{NH}_{4} \mathrm{Cl} \text {-fertilised }\left(31.4 \mathrm{~kg} \mathrm{Nha}^{-1} \mathrm{yr}^{-1} \text {; }\right. \\
\text { chronic } \mathrm{N} \text { addition exp.; measurement in } \\
\text { the beginning of the } 3 . \mathrm{yr} \text { (only growing } \\
\text { season), estimated annual } \mathrm{N}_{2} \mathrm{O} \text { flux of } \\
0.11 \mathrm{~kg} \mathrm{Nha}^{-1} \mathrm{yr}^{-1} \text { ); USA }\end{array}$ & Castro et al. (1993) \\
\hline & & -1.12 & & & $\begin{array}{l}\text { Unfertilised }\left(10 \mathrm{~kg} \mathrm{Nha}^{-1} \mathrm{yr}^{-1} \text { wet }+ \text { dry }\right. \\
\text { deposition; measurement only in the } \\
\text { growing season); USA }\end{array}$ & \\
\hline & & 1.1 (drained); 2.9 (wet) & $0.1{\text { (drained) } 0.6 \text { (wet }^{\mathrm{e}}}^{\mathrm{e}}$ & $\mathrm{EF}_{\mathrm{FB}}$ & $\begin{array}{l}\mathrm{NH}_{4} \mathrm{NO}_{3} \text {-fertilised }\left(35 \mathrm{~kg} \mathrm{Nha}^{-1} \mathrm{yr}^{-1} \text { in }\right. \\
\text { small doses; chronic } \mathrm{N} \text { addition exp.; } \\
\text { measurement after } 2 \mathrm{yr} \text {; Sweden) }\end{array}$ & Klemedtsson et al. (1997) \\
\hline & & 0.8 (drained); 1.3 (wet) & & & $\begin{array}{l}\text { Unfertilised ( } 12 \mathrm{~kg} \mathrm{Nha}^{-1} \mathrm{yr}^{-1} \\
\text { deposition; Sweden) }\end{array}$ & \\
\hline & & 0.9 & $<0.1^{\mathrm{e}}$ & $\mathrm{EF}_{\mathrm{F}}$ & $\begin{array}{l}\left(\mathrm{NH}_{4}\right)_{2} \mathrm{SO}_{4} \text {-fertilised }\left(150 \mathrm{~kg} \mathrm{~N} \mathrm{ha}^{-1}\right. \\
\text { single dose; measurement in the first } 3 \mathrm{yr} ; \\
\text { Germany) }\end{array}$ & Papen et al. (2001) \\
\hline & & -1.0 & & & Unfertilised (Germany) & \\
\hline & & 45.8 & 0.93 (1 month) & $\mathrm{EF}_{\mathrm{FB}}$ & $\begin{array}{l}\mathrm{NH}_{4} \mathrm{NO}_{3} \text {-fertilised }\left(90 \mathrm{~kg} \mathrm{~N} \mathrm{ha}^{-1} \text {; single }\right. \\
\text { dose; measurement over } 1 \text { month; } \\
\text { Norway) }\end{array}$ & Sitaula et al. $(1995)^{\mathrm{b}}$ \\
\hline & & 21.7 & 0.94 (1 month) & $\mathrm{EF}_{\mathrm{FB}}$ & $\begin{array}{l}\mathrm{NH}_{4} \mathrm{NO}_{3} \text {-fertilised }\left(30 \mathrm{~kg} \mathrm{Nha}^{-1} \text {; single }\right. \\
\text { dose; measurement over } 1 \text { month; } \\
\text { Norway) }\end{array}$ & \\
\hline & & 8.3 & & & Unfertilised (Norway) & \\
\hline & & 5.7 & $0.6^{\mathrm{e}}$ & $\mathrm{EF}_{\mathrm{FB}}$ & $\begin{array}{l}\text { Acid mist-fertilised }\left(96 \mathrm{~kg} \mathrm{~N} \mathrm{ha}^{-1} \mathrm{yr}^{-1} \text {; }\right. \\
\text { chronic } \mathrm{N} \text { addition exp.; measurement } \\
\text { after } 2 \mathrm{yr} \text {; UK) }\end{array}$ & Skiba et al. $(1998,1999)$ \\
\hline & & 0.5 & $0.2^{\mathrm{e}}$ & $\mathrm{EF}_{\mathrm{FB}}$ & $\begin{array}{l}\text { Acid mist-fertilised ( } 48 \mathrm{~kg} \mathrm{Nha}^{-1} \mathrm{yr}^{-1} \text {; } \\
\text { chronic } \mathrm{N} \text { addition exp.; measurement in } \\
\text { the } 3 . \mathrm{yr} \text {, UK) }\end{array}$ & \\
\hline & & -0.3 & & & $\begin{array}{l}\text { Unfertilised }\left(6.7 \mathrm{~kg} \mathrm{Nha}^{-1} \mathrm{yr}^{-1} \text { wet }+\right. \\
\text { dry deposition; UK) }\end{array}$ & \\
\hline & & $<10$ & $<0.3$ & $\mathrm{EF}_{\mathrm{F}}$ & $\begin{array}{l}\mathrm{NH}_{4} \mathrm{NO}_{3} \text {-fertilised }\left(150 \mathrm{~kg} \mathrm{Nha}^{-1} \mathrm{yr}^{-1} \text {; }\right. \\
\text { chronic } \mathrm{N} \text { addition exp.; } \\
\text { measurement in the 13. yr; USA) }\end{array}$ & Venterea et al. (2003) \\
\hline & & $<10$ & $<0.3$ & $\mathrm{EF}_{\mathrm{F}}$ & $\begin{array}{l}\mathrm{NH}_{4} \mathrm{NO}_{3} \text {-fertilised }\left(50 \mathrm{~kg} \mathrm{Nha}^{-1} \mathrm{yr}^{-1} \text {; }\right. \\
\text { chronic } \mathrm{N} \text { addition exp.; } \\
\text { measurement in the 13. yr; USA) }\end{array}$ & \\
\hline & & $<10$ & $<0.3$ & $\mathrm{EF}_{\mathrm{F}}$ & $\begin{array}{l}\text { Unfertilised }\left(8 \mathrm{~kg} \mathrm{Nha}^{-1} \mathrm{yr}^{-1} \text { wet }+ \text { dry }\right. \\
\text { deposition; USA) }\end{array}$ & \\
\hline
\end{tabular}

e.g. from unfertilised plots in fertilisation experiments. In contrast to $\mathrm{EF}_{\mathrm{FB}}$, the $\mathrm{EF}_{\mathrm{F}}$ does not distinguish between possible background emissions and emissions directly derived from $\mathrm{N}$ deposition. Consequently values of $\mathrm{EF}_{\mathrm{F}}$ of the fraction method will overestimate direct $\mathrm{N}_{2} \mathrm{O}$ emissions from deposition because it does not correct for such possible $\mathrm{N}_{2} \mathrm{O}$ background emissions.

Emission factors based on fertilised plots $\left(\mathrm{EF}_{\mathrm{FB}}\right)$ were in the same order of magnitude in our study as our $\mathrm{EF}_{15} \mathrm{~N}$ values obtained by the ${ }^{15} \mathrm{~N}$ tracer method. However, strong increases in $\mathrm{N}_{2} \mathrm{O}$ fluxes from the fertilised plots compared to the unfertilised control plots have been reported (Table 5), which may result from the high mineral $\mathrm{N}$ concentrations following fertiliser application, which does not reflect conditions during atmospheric N deposition (Sitaula et al., 1995; Skiba and Smith, 2000) and may cause a positive priming effect (e.g. Fenn et al., 1998). Also the implicit assumption of the regression approach is that the $\mathrm{N}_{2} \mathrm{O}$ emissions from $\mathrm{N}$ cycling are not affected by $\mathrm{N}$ depositions. However, this assumption may not be valid and may lead to artificially high estimates since both $\mathrm{N}$ deposition and $\mathrm{N}_{2} \mathrm{O}$ fluxes are frequently positively related to a number of factors. Some of those factors also affect $\mathrm{N}_{2} \mathrm{O}$ fluxes in a positive way causing systematic error of overestimating the $\mathrm{EF}_{\mathrm{R}}$ values. For 
Table 5. Continued.

\begin{tabular}{|c|c|c|c|c|c|c|}
\hline Forest type & Type of $\mathrm{N}$ input & $\begin{array}{l}\mathrm{N}_{2} \mathrm{O} \\
{\left[\mu \mathrm{g} \mathrm{N} \mathrm{m}^{-2} \mathrm{~h}^{-1}\right]}\end{array}$ & $\begin{array}{l}\text { Emission } \\
\text { factor [\%] }\end{array}$ & $\begin{array}{l}\text { Method } \\
\text { used }\end{array}$ & Treatment & Reference \\
\hline \multirow[t]{17}{*}{ Coniferous } & \multirow[t]{15}{*}{ Deposition } & 2.9 & $0.6^{\mathrm{e}}$ & $\mathrm{EF}_{\mathrm{F}}$ & $\begin{array}{l}41 \mathrm{~kg} \mathrm{Nha}^{-1} \mathrm{yr}^{-1} \text { throughfall deposition } \\
\text { (Germany) }\end{array}$ & \multirow[t]{3}{*}{ Brumme et al. (1999) } \\
\hline & & 2.4 & $0.7^{\mathrm{e}}$ & $\mathrm{EF}_{\mathrm{F}}$ & $\begin{array}{l}31 \mathrm{~kg} \mathrm{Nha}^{-1} \mathrm{yr}^{-1} \text { throughfall deposition } \\
\text { (Germany) }\end{array}$ & \\
\hline & & 14.8 & $6.5^{\mathrm{e}}$ & $\mathrm{EF}_{\mathrm{F}}$ & $\begin{array}{l}20 \mathrm{~kg} \mathrm{~N} \mathrm{ha}^{-1} \mathrm{yr}^{-1} \text { throughfall deposition } \\
\text { without } \mathrm{N}_{\mathrm{org}}(\mathrm{Germany})\end{array}$ & \\
\hline & & $4-15$ & $1.2-4.4^{\mathrm{e}}$ & $\mathrm{EF}_{\mathrm{F}}$ & $30 \mathrm{~kg} \mathrm{~N} \mathrm{ha}^{-1} \mathrm{yr}^{-1}$ wet deposition (Germany) & \multirow[t]{2}{*}{ Butterbach-Bahl et al. (1998) ${ }^{\mathrm{a}}$} \\
\hline & & $-0.5-2.1$ & $\sim 1.3^{\mathrm{e}}$ & $\mathrm{EF}_{\mathrm{F}}$ & $5-6 \mathrm{~kg} \mathrm{~N} \mathrm{ha}^{-1} \mathrm{yr}^{-1}$ wet deposition (Ireland) & \\
\hline & & $16-32$ & $\sim 7-13^{\mathrm{e}}$ & $\mathrm{EF}_{\mathrm{F}}$ & $\begin{array}{l}20-22 \mathrm{~kg} \mathrm{~N} \mathrm{ha}^{-1} \mathrm{yr}^{-1} \text { wet deposition } \\
\text { (Germany) }\end{array}$ & \multirow[t]{2}{*}{ Butterbach-Bahl et al. (2002) ${ }^{\mathrm{a}}$} \\
\hline & & $5-10$ & $\sim 4.4^{\mathrm{e}}$ & $\mathrm{EF}_{\mathrm{F}}$ & $\begin{array}{l}\sim 15 \mathrm{~kg} \mathrm{Nha}^{-1} \mathrm{yr}^{-1} \text { wet deposition } \\
\text { (Germany) }\end{array}$ & \\
\hline & & $3.4-4.7$ & $2.5-3.5$ & $\mathrm{EF}_{\mathrm{F}}$ & $\begin{array}{l}10.6-11.9 \mathrm{~kg} \mathrm{~N} \mathrm{ha}^{-1} \mathrm{yr}^{-1} \text { bulk deposition } \\
\text { (Austria) }\end{array}$ & Kitzler et al. $(2006 b)^{c}$ \\
\hline & & 3.8 & $\sim 1$ & $\mathrm{EF}_{\mathrm{FB}}$ & $\sim 46.2 \mathrm{~kg} \mathrm{~N} \mathrm{ha}^{-1} \mathrm{yr}^{-1}$ total deposition (UK) & \multirow[t]{2}{*}{ Macdonald et al. (1997) } \\
\hline & & 1.3 & & & $6.4 \mathrm{~kg} \mathrm{~N} \mathrm{ha}^{-1} \mathrm{yr}^{-1}$ total deposition (UK) & \\
\hline & & 4.3 & 1.23 & $\mathrm{EF}_{\mathrm{F}}$ & $\begin{array}{l}30.6 \mathrm{~kg} \mathrm{~N} \mathrm{ha}^{-1} \mathrm{yr}^{-1} \text { throughfall deposition } \\
\text { (Japan) }\end{array}$ & Oura et al. (2001) \\
\hline & & 16.4 & 0.5 & $\mathrm{EF}_{\mathrm{R}}$ & $30 \mathrm{~kg} \mathrm{~N} \mathrm{ha}^{-1} \dot{\mathrm{yr}}^{-1}$ wet deposition (Germany) & Papen and Butterbach-Bahl (1999) \\
\hline & & 56 & 6 & $\mathrm{EF}_{\mathrm{FB}}$ & $\begin{array}{l}80.1 \mathrm{~kg} \mathrm{Nha}^{-1} \mathrm{yr}^{-1} \mathrm{NH}_{3} \text { dep from poultry } \\
\text { farm; } \\
30 \mathrm{~m} \text { down-wind from farm (UK) }\end{array}$ & \multirow[t]{2}{*}{ Skiba et al. $(1998,1999)^{\mathrm{d}}$} \\
\hline & & 13 & & & $\begin{array}{l}17.4 \mathrm{~kg} \mathrm{Nha}^{-1} \mathrm{yr}^{-1} \mathrm{NH}_{3} \text { dep from poultry } \\
\text { farm; }\end{array}$ & \\
\hline & & 3.4 & 0.9 & $\mathrm{EF}_{\mathrm{F}}$ & $\begin{array}{l}250 \mathrm{~m} \text { down-wind from farm (UK) } 33 \mathrm{~kg} \mathrm{~N} \mathrm{ha}^{-1} \mathrm{yr}^{-1} \text { throughfall deposition } \\
\text { (Germany) }\end{array}$ & This study \\
\hline & \multirow{2}{*}{${ }^{15} \mathrm{~N}$ tracer } & & & & & \\
\hline & & 3.4 & 0.1 & $\mathrm{EF}_{15} \mathrm{~N}$ & $\begin{array}{l}33 \mathrm{~kg} \mathrm{Nha}^{-1} \mathrm{yr}^{-1} \text { throughfall deposition } \\
\text { (Germany) }\end{array}$ & This study \\
\hline
\end{tabular}

$\mathrm{EF}_{\mathrm{F}}$ : emission factor represented the fraction of $\mathrm{N}$ input that is re-emitted: $\mathrm{EF}_{\mathrm{F}}=$ flux/ $\mathrm{N}$ input $\cdot 100 . \mathrm{EF}_{\mathrm{FB}}$ : emission factor calculated for $\mathrm{N}$ fertilisation experiments or $\mathrm{N}$ deposition gradients, where $\mathrm{N}_{2} \mathrm{O}$ background emissions are considered. Calculated for $\mathrm{N}$ fertilisation experiments: $\mathrm{EF}_{\mathrm{FB}}=($ flux from fertilised plot - flux from control plot)/ $\mathrm{N}$ amount in fertiliser - 100. Calculated for $\mathrm{N}$ deposition gradients: $\mathrm{EF}_{\mathrm{FB}}=(($ flux at high $\mathrm{N}$ input - flux at background $\mathrm{N}$ input $) /($ high $\mathrm{N}$ input - background $\mathrm{N}$ input $)) \cdot 100$. $\mathrm{EF} \mathrm{R}_{\mathrm{R}}$ : emission factors were derived from regression analyses between $\mathrm{N}_{2} \mathrm{O}$ fluxes and $\mathrm{N}$ deposition rates. $\mathrm{EF}_{15_{\mathrm{N}}}$ : emission factors were derived from ${ }^{15} \mathrm{~N}$ tracer experiments; for calculations see this study.

a The compared sites were similar in climatic and edaphic conditions.

${ }^{b}$ Lysimeter study with re-established soil profiles from Scots pine forest.

c Spruce-fir-beech forest.

d Mixed woodland of pine, birch, oak, rowan, and elder.

${ }^{\mathrm{e}}$ Emission factor was calculated by the authors of this study.

an example, at times of high rainfall (and thus, high $\mathrm{N}$ deposition), high soil water content will stimulate denitrification and therefore $\mathrm{N}_{2} \mathrm{O}$ fluxes, which originate mainly from $\mathrm{N}$ cycling in the soil and not from direct $\mathrm{N}$ deposition. The problem of complex relationships was further highlighted by the reduction of the calculated $\mathrm{EF}_{\mathrm{R}}$ from $25 \%$ to $8.6 \%$ in our beech stand when soil temperature was included in the regression equation. Our study demonstrated that $\mathrm{EF}_{15_{\mathrm{N}}}$ values represent reliable and direct values of emissions by inorganic $\mathrm{N}$ depositions.

The low values of direct contribution of atmospheric depositions to $\mathrm{N}_{2} \mathrm{O}$ emissions raise the question whether the background emissions are affected by decade long atmospheric $\mathrm{N}$ depositions, most of which may have been accumulated in the ecosystems. $\mathrm{N}$ cycling rates may have considerably changed due to long-term $\mathrm{N}$ depositions (Corre et al., 2007).
With the methods employed here it was not possible to assess the effect of accumulated anthropogenic $\mathrm{N}$ on the background $\mathrm{N}_{2} \mathrm{O}$ emissions. However, the literature compilation indicates that, in general, soils with a similar forest type but with higher $\mathrm{N}$ depositions had higher $\mathrm{N}_{2} \mathrm{O}$ emissions than soils exposed to lower $\mathrm{N}$ depositions (Table 5). Assuming that $\mathrm{N}_{2} \mathrm{O}$ emissions were negligible before the onset of anthropogenic activity, the total contribution of $\mathrm{N}$ deposition to $\mathrm{N}_{2} \mathrm{O}$ emission (direct and background emissions) is probably best described by the fraction of $\mathrm{N}_{2} \mathrm{O}$ to current $\mathrm{N}$ deposition $\left(\mathrm{EF}_{\mathrm{F}}\right)$. To obtain a representative $\mathrm{EF}_{\mathrm{F}}$ value, mean values covering several years are necessary. This is illustrated by the mean $\mathrm{EF}_{\mathrm{F}}$ value calculated for the beech stand from 1990 to $1998(8.2 \% \pm 0.7 \%)$ compared to the higher $\mathrm{EF}_{\mathrm{F}}$ calculated for 2007 to 2008 when $\mathrm{N}$ depositions were comparably low and $\mathrm{N}_{2} \mathrm{O}$ emissions were comparably high. 


\section{Conclusions}

The ${ }^{15} \mathrm{~N}$ tracer method proved to be a precise approach for quantifying the direct contribution of atmospheric $\mathrm{N}$ deposition to the emission of $\mathrm{N}_{2} \mathrm{O}$. The technique allows the simulation of atmospheric throughfall $\mathrm{N}$ deposition without artificial fertilisation. The method provides the possibility to investigate the impact of $\mathrm{N}$ deposition on $\mathrm{N}_{2} \mathrm{O}$ emissions in forests also when direct emissions are low. In contrast to the regression approach, this method does not include artefacts which may result from controlling rainfall or temperature conditions, as both would influence $\mathrm{N}_{2} \mathrm{O}$ fluxes and $\mathrm{N}$ depositions. There are no uncertainties resulting from the comparison of different sites (as when regarding deposition gradients), which are usually not completely comparable in climate and soil conditions. Furthermore, EFs when calculated from fertilised plots may result in artificially high $\mathrm{N}_{2} \mathrm{O}$ emissions because the pulse in mineral $\mathrm{N}$ concentrations does not reflect the true atmospheric $\mathrm{N}$ depositions and may also cause positive priming effects on the $\mathrm{N}$ cycling in soils. Whereas most of the other methods overestimate the direct emissions, the ${ }^{15} \mathrm{~N}$ tracer method is a useful tool to measure direct emissions or background emissions.

\section{Supplementary material related to this article is available online at: http://www.biogeosciences.net/8/621/2011/ bg-8-621-2011-supplement.pdf.}

Acknowledgements. The authors thank Henning Meesenburg and Norbert Lamersdorf for providing the precipitation and deposition data. This work was financially supported by the German Research Foundation (BR 1524/6-1).

Edited by: C. Spirig

\section{References}

Aber, J., McDowell, W., Nadelhoffer, K., Magill, A., Berntson, G., Kamakea, M., McNulty, S., Currie, W., Rustad, L., and Fernandez, I. J.: Nitrogen saturation in temperate forest ecosystems, Bioscience, 48(11), 921-934, 1998.

Ambus, P., Zechmeister-Boltenstern, S., and Butterbach-Bahl, K.: Sources of nitrous oxide emitted from European forest soils, Biogeosciences, 3, 135-145, doi:10.5194/bg-3-135-2006, 2006.

Ball, B.C., Smith, K. A., Klemedtsson, L., Brumme, R., Sitaula, B. K., Hansen, S., Prieme, A., MacDonald, J., and Horgan, G. W.: The influence of soil gas transport properties on methane oxidation in a selection of northern European soils, J. Geophys. Res., 102(D19), 23309-23317, 1997.

Beier, C., Rasmussen, L., Pilegaard, K., Ambus, P., Mikkelsen, T., Jensen, N. O., Kjoller, A., Prieme, A., and Ladekarl, U. L.: Fluxes of $\mathrm{NO}_{3}^{-}, \mathrm{NH}_{4}^{+}, \mathrm{NO}, \mathrm{NO}_{2}$, and $\mathrm{N}_{2} \mathrm{O}$ in an old Danish beech forest, Water. Air Soil Poll., 1(1), 187-195, 2001.
Berge, E., Bartnicki, J., Olendrzynski, K., and Tsyro, S. G.: Longterm trends in emissions and transboundary transport of acidifying air pollution in Europe, J. Environ. Manag., 57(1), 31-50, 1999.

Bowden, R. D., Melillo, J. M., Steudler, P. A., and Aber, J. D.: Effects of nitrogen additions on annual nitrous oxide fluxes from temperate forest soils in the northeastern United States, J. Geophys. Res., 96(D5), 9321-9328, 1991.

Bredemeier, M., Blanck, K., Lamersdorf, N., and Wiedey, G. A.: Response of soil water chemistry to experimental "clean rain" in the NITREX roof experiment at Solling, Germany, For. Ecol. Manag., 71, 31-44, 1995.

Bredemeier, M., Blanck, K., Dohrenbusch, A., Lamersdorf, N., Meyer, A. C., Murach, D., Parth, A., and Xu, Y.-J.: The Solling roof project - site characteristics, experiments and results, For. Ecol. Manag., 101, 281-293, 1998.

Brumme, R. and Beese, F.: Effects of liming and nitrogen fertilization on emissions of $\mathrm{CO}_{2}$ and $\mathrm{N}_{2} \mathrm{O}$ from a temperate forest, $\mathrm{J}$ Geophys. Res., 97(D12), 12851-12858, 1992.

Brumme, R. and Khanna, P. K.: Ecological and site historical aspects of $\mathrm{N}$ dynamics and current $\mathrm{N}$ status in temperate forests, Glob. Change Biol., 14(1), 125-141, 2008.

Brumme, R. and Khanna, P. K.: Functioning and management of European beech ecosystems, Ecol Stud, 208, Springer-Verlag, Berlin Heidelberg, 490 pp., 2009a.

Brumme, R. and Khanna, P. K.: Chapter 23: Stand, soil and nutrient factors determining the functioning and management of beech forest ecosystems: A Synopsis, in: Functioning and management of European beech ecosystems, edited by: Brumme, R. and Khanna, P. K., Springer-Verlag, Berlin Heidelberg, 459-490, 2009b.

Brumme, R., Borken, W., and Finke, S.: Hierarchical control on nitrous oxide emission in forest ecosystems, Global Biogeochem. Cy., 13(4), 1137-1148, 1999.

Brumme, R., Verchot, L. V., Martikainen, P. J., and Potter, C. S.: Contribution of trace gases nitrous oxide $\left(\mathrm{N}_{2} \mathrm{O}\right)$ and methane $\left(\mathrm{CH}_{4}\right)$ to the atmospheric warming balance of forest biomes, in: The carbon balance of forest biomes, edited by: Griffiths, $\mathrm{H}$. and Jarvis, P. G., Thomson Publishing Services, Hampshire, UK, 293-317, 2005.

Butterbach-Bahl, K., Gasche, R., Huber, C., Kreutzer, K., and Papen, $\mathrm{H}$.: Impact of $\mathrm{N}$-input by wet deposition on $\mathrm{N}$-trace gas fluxes and $\mathrm{CH}_{4}$-oxidation in spruce forest ecosystems of the temperate zone in Europe, Atmos. Environ., 32(3), 559-564, 1998.

Butterbach-Bahl, K., Stange, F., Papen, H., and Li, C. S.: Regional inventory of nitric oxide and nitrous oxide emissions for forest soils of southeast Germany using the biogeochemical model PnET-N-DNDC, J. Geophys. Res., 106(D24), 3415534166, 2001.

Butterbach-Bahl, K., Breuer, L., Gasche, R., Willibald, G., and Papen, H.: Exchange of trace gases between soils and the atmosphere in Scots pine forest ecosystems of the northeastern German lowlands 1 . Fluxes of $\mathrm{N}_{2} \mathrm{O}, \mathrm{NO} / \mathrm{NO}_{2}$ and $\mathrm{CH}_{4}$ at forest sites with different N-deposition, For. Ecol. Manag., 167(1-3), 123134, 2002.

Castro, M., Steudler, P., Melillo, J., Aber, J., and Millham, S.: Exchange of $\mathrm{N}_{2} \mathrm{O}$ and $\mathrm{CH}_{4}$ between the atmosphere and soils in spruce-fir forests in the northeastern United States, Biogeochemistry, 18(3), 119-135, 1993. 
Corre, M. D. and Lamersdorf, N. P.: Reversal of nitrogen saturation after long-term deposition reduction: impact on soil nitrogen cycling, Ecology, 85(11), 3090-3104, 2004.

Corre, M. D., Brumme, R., Veldkamp, E., and Beese, F. O.: Changes in nitrogen cycling and retention processes in soils under spruce forests along a nitrogen enrichment gradient in Germany, Glob. Change Biol., 13(7), 1509-1527, 2007.

Crawley, M. J.: The R Book, John Wiley \& Sons Ltd, Chichester, 942 pp., 2007.

Crutzen, P. J.: The Role of $\mathrm{NO}$ and $\mathrm{NO}_{2}$ in the chemistry of the troposphere and stratosphere, Annu. Rev. Earth Planet. Sci., 7(1), 443-472, 1979.

Denier van der Gon, $\mathrm{H}$. and Bleeker, A.: Indirect $\mathrm{N}_{2} \mathrm{O}$ emission due to atmospheric $\mathrm{N}$ deposition for the Netherlands, Atmos. Environ., 39(32), 5827-5838, 2005.

Feng, Z., Brumme, R., Xu, Y.-J., and Lamersdorf, N.: Tracing the fate of mineral $\mathrm{N}$ compounds under high ambient $\mathrm{N}$ deposition in a Norway spruce forest at Solling/Germany, For. Ecol. Manag., 255, 2061-2073, 2008.

Fenn, M. E., Poth, M. A., Aber, J. D., Baron, J. S., Bormann, B. T., Johnson, D. W., Lemly, A. D., McNulty, S. G., Ryan, D. F., and Stottlemyer, R.: Nitrogen excess in North American ecosystems: Predisposing factors, ecosystem response, and management Strategies, Ecol. Appl., 8(3), 706-733, 1998.

Galloway, J. N., Townsend, A. R., Erisman, J. W., Bekunda, M., Cai, Z. C., Freney, J. R., Martinelli, L. A., Seitzinger, S. P., and Sutton, M. A.: Transformation of the nitrogen cycle: Recent trends, questions, and potential solutions, Science, 320(5878), 889-892, 2008.

Gueorguieva, R. and Krystal, J. H.: Move over ANOVA, progress in analyzing repeated-measures data and its reflection in papers published in the archives of general psychiatry, Arch. Gen. Psychiatry, 61, 310-317, 2004.

IPCC: Chapter 4: Atmospheric chemistry and greenhouse gases, in: Climate Change 2001: Working Group I: The scientific basis. Contribution of Working Group I to the Third Assessment Report of the Intergovernmental Panel on Climate Change., edited by: Houghton, J. T., Ding, Y., Griggs, D. J., Noguer, M., van der Linden, P. J., Dai, X., Maskell, K., and Johnson, C. A., Cambridge University Press, Cambridge, UK and New York, USA, 2001

IPCC: Chapter 11: $\mathrm{N}_{2} \mathrm{O}$ Emissions from managed soils, and $\mathrm{CO}_{2}$ emissions from lime and urea application, in: IPCC guidelines for national greenhouse gas inventories, edited by: Eggleston, H. S., Buendia, L., Miwa, K., Ngara, T., and Tanabe, K., IGES, Hayama, Japan, 2006.

IPCC: Changes in atmospheric constituents and in radiative forcing, in: Climate Change 2007: The physical science basis. Contribution of Working Group I to the Fourth Assessment Report of the Intergovernmental Panel on Climate Change, edited by: Solomon, S., Qin, D., Manning, M., Chen, Z., Marquis, M., Averyt, K. B., Tignor, M., and Miller, H. L., Cambridge University Press, Cambridge, UK and New York, USA, 2007.

Kitzler, B., Zechmeister-Boltenstern, S., Holtermann, C., Skiba, U., and Butterbach-Bahl, K.: Nitrogen oxides emission from two beech forests subjected to different nitrogen loads, Biogeosciences, 3, 293-310, doi:10.5194/bg-3-293-2006, 2006 a.

Kitzler, B., Zechmeister-Boltenstern, S., Holtermann, C., Skiba, U., and Butterbach-Bahl, K.: Controls over $\mathrm{N}_{2} \mathrm{O}, \mathrm{NO}_{\mathrm{x}}$ and $\mathrm{CO}_{2}$ fluxes in a calcareous mountain forest soil, Biogeosciences, 3, 383-395, doi:10.5194/bg-3-383-2006, 2006b.

Klemedtsson, L., Klemedtsson, A. K., Moldan, F., and Weslien, P.: Nitrous oxide emission from Swedish forest soils in relation to liming and simulated increased N-deposition, Biol. Fertil. Soils, 25(3), 290-295, 1997.

Kroeze, C., Mosier, A., and Bouwman, L.: Closing the global $\mathrm{N}_{2} \mathrm{O}$ budget: A retrospective analysis 1500-1994, Global Biogeochem. Cy., 13(1), 1-8, 1999.

Kroeze, C., Bouwman, L., and Slomp, C. P.: Sinks for Nitrous Oxide at the Earth's Surface, in: Greenhouse Gas Sinks, edited by: Reay, D., Hewitt, C. N., Smith, K., and Grace, J., CAB International, Oxfordshire, UK, 227-242, 2007.

Loftfield, N., Flessa, H., Augustin, J., and Beese, F.: Automated gas chromatographic system for rapid analysis of atmospheric trace gases methane, carbon dioxide, and nitrous oxide, J. Environ. Qual., 26, 560-564, 1997.

Macdonald, J. A., Skiba, U., Sheppard, L. J., Ball, B., Roberts, J. D., Smith, K. A., and Fowler, D.: The effect of nitrogen deposition and seasonal variability on methane oxidation and nitrous oxide emission rates in an upland spruce plantation and moorland, Atmos. Environ., 31(22), 3693-3706, 1997.

Meesenburg, H., Eichhorn, J., and Meiwes, K. J.: Chapter 15: Atmospheric deposition and canopy interactions, in: Functioning and management of European beech ecosystems, edited by: Brumme, R. and Khanna, P. K., Springer-Verlag, Berlin Heidelberg, 265-302, 2009.

Oura, N., Shindo, J., Fumoto, T., Toda, H., and Kawashima, H.: Effects of nitrogen deposition on nitrous oxide emissions from forest floor, Water Air Soil Pollut., 130, 673-678, 2001.

Papen, H. and Butterbach-Bahl, K.: A 3-year continuous record of nitrogen trace gas fluxes from untreated and limed soil of a $\mathrm{N}$-saturated spruce and beech forest ecosystem in Germany 1. $\mathrm{N}_{2} \mathrm{O}$ emissions, J. Geophys. Res., 104(D15), 18487-18503, 1999.

Papen, H., Daum, M., Steinkamp, R., and Butterbach-Bahl, K.: $\mathrm{N}_{2} \mathrm{O}$ and $\mathrm{CH}_{4}$-fluxes from soils of a $\mathrm{N}$-limited and $\mathrm{N}$-fertilized spruce forest ecosystem of the temperate zone, J. Appl. Bot., 75(3-4), 159-163, 2001

Pataki, D. E., Ehleringer, J. R., Flanagan, L. B., Yakir, D., Bowling, D. R., Still, C. J., Buchmann, N., Kaplan, J. O., and Berry, J. A.: The application and interpretation of Keeling plots in terrestrial carbon cycle research, Global Biogeochem. Cy., 17(1), 10221029, 2003.

Pilegaard, K., Skiba, U., Ambus, P., Beier, C., Brggemann, N., Butterbach-Bahl, K., Dick, J., Dorsey, J., Duyzer, J., Gallagher, M., Gasche, R., Horvath, L., Kitzler, B., Leip, A., Pihlatie, M. K., Rosenkranz, P., Seufert, G., Vesala, T., Westrate, H., and Zechmeister-Boltenstern, S.: Factors controlling regional differences in forest soil emission of nitrogen oxides ( $\mathrm{NO}$ and $\mathrm{N}_{2} \mathrm{O}$ ), Biogeosciences, 3, 651-661, doi:10.5194/bg-3-651-2006, 2006.

R Development Core Team: R: A language and environment for statistical computing, R Foundation for Statistical Computing, Vienna, Austria, ISBN 3-900051-07-0, available at: http://www. R-project.org, 2009.

Rennenberg, H., Kreutzer, K., Papen, H., and Weber, P.: Consequences of high loads of nitrogen for spruce (Picea abies) and beech (Fagus sylvatica) forests, New Phytol, 139(1), 71-86, 1998. 
Sitaula, B. K., Bakken, L. R., and Abrahamsen, G.: N-Fertilization and Soil Acidification Effects on $\mathrm{N}_{2} \mathrm{O}$ and $\mathrm{CO}_{2}$ Emission from Temperate Pine Forest Soil, Soil. Biol. Biochem., 27(11), 14011408, 1995.

Skiba, U. and Smith, K. A.: The control of nitrous oxide emissions from agricultural and natural soils, Chemosphere, 2, 379-386, 2000.

Skiba, U., Sheppard, L., Pitcairn, C. E. R., Leith, I., Crossley, A., van Dijk, S., Kennedy, V. H., and Fowler, D.: Soil nitrous oxide and nitric oxide emissions as indicators of elevated atmospheric $\mathrm{N}$ deposition rates in seminatural ecosystems, Environ. Pollut., 102, 457-461, 1998.

Skiba, U., Sheppard, L. J., Pitcairn, C. E. R., van Dijk, S., and Rossall, M.: The effect of $\mathrm{N}$ deposition on nitrous oxide and nitric oxide emissions from temperate forest soils, Water Air Soil Pollut., 116, 89-98, 1999.

Tilsner, J., Wrage, N., Lauf, J., and Gebauer, G.: Emission of gaseous nitrogen oxides from an extensively managed grassland in NE Bavaria, Germany II. Stable isotope natural abundance of $\mathrm{N}_{2} \mathrm{O}$, Biogeochemistry, 63(3), 249-267, 2003.
Venterea, R. T., Groffman, P. M., Verchot, L. V., Magill, A. H., Aber, J. D., and Steudler, P. A.: Nitrogen oxide gas emissions from temperate forest soils receiving long-term nitrogen inputs, Glob. Change Biol., 9(3), 346-357, 2003.

Vitousek, P. M., Aber, J. D., Howarth, R. W., Likens, G. E., Matson, P. A., Schindler, D. W., Schlesinger, W. H., and Tilman, D. G.: Human alteration of the global nitrogen cycle: sources and consequences, Ecol. Appl., 7(3), 737-750, 1997.

Wolf, I. and Brumme, R.: Contribution of nitrification and denitrification sources for seasonal $\mathrm{N}_{2} \mathrm{O}$ emissions in acid German forest soil, Soil Biol. Biochem., 34, 741-744, 2002.

Zechmeister-Boltenstern, S., Hahn, M., Meger, S., and Jandl, R.: Nitrous oxide emissions and nitrate leaching in relation to microbial biomass dynamics in a beech forest soil, Soil Biol. Biochem., 34(6), 823-832, 2002. 